\title{
A review of the common crab genus Macromedaeus Ward, 1942 (Brachyura, Xanthidae) from China Seas with description of a new species using integrative taxonomy methods
}

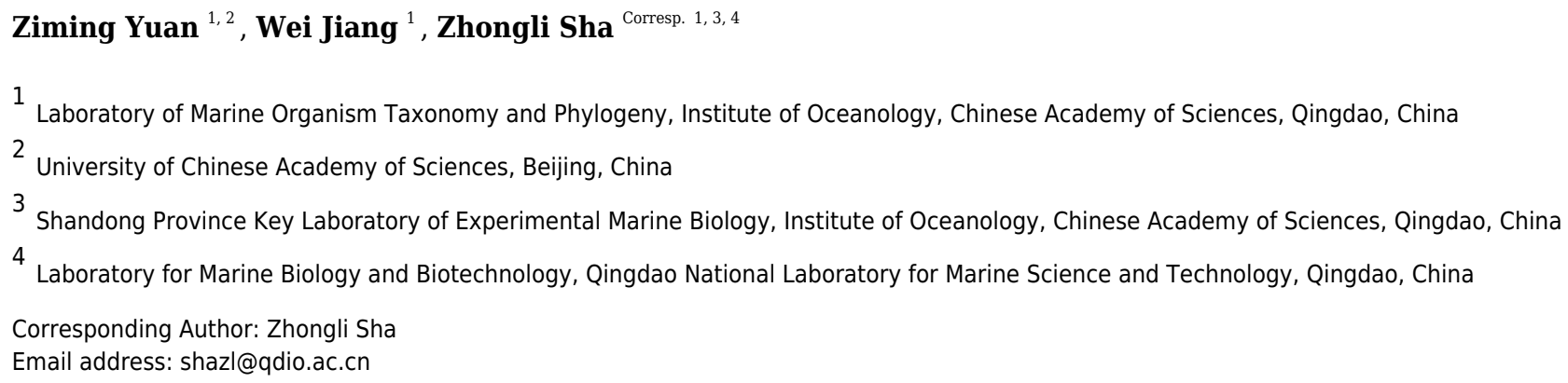

Macromedaeus is one of the most common xanthid genera in shallow waters of the IndoWest Pacific. In this study, we describe a new species, Macromedaeus hainanensis sp. nov., and report on two newly recorded species, M. quinquedentatus (Krauss, 1843) and $M$. orientalis (Takeda \& Miyake, 1969) from Hainan Island, South China Sea. M. hainanensis is most related to $M$. distinguendus (De Haan, 1835) and $M$. orientalis on the carapace shape and granular appearance, but can be distinguished by unique morphological characteristics especially its front, pereopods and male first gonopod. Taxonomic identities of the six Macromedaeus species recorded from China seas are discussed, and a phylogenetic analyzation is performed on Macromedaeus and related taxa based on three mitochondrial and two nuclear markers (12S, 16S, COI, H3, 18S). Integrated taxonomic evidence is used to support the taxonomic status of each species. 


\section{A review of the common crab genus Macromedaeus Ward,}

21942 (Brachyura, Xanthidae) from China Seas with

3 description of a new species using integrative taxonomy

4 methods

5 Ziming Yuan ${ }^{1,4}$, Wei Jiang ${ }^{1}$, Zhongli Sha ${ }^{\text {Corresp. 1, 2,3 }}$

61 Laboratory of Marine Organism Taxonomy and Phylogeny, Institute of Oceanology, Chinese

7 Academy of Sciences, Qingdao, China

82 Shandong Province Key Laboratory of Experimental Marine Biology, Institute of Oceanology,

9 Chinese Academy of Sciences

103 Laboratory for Marine Biology and Biotechnology, Qingdao National Laboratory for Marine

11 Science and Technology, Qingdao, China

124 University of Chinese Academy of Sciences, Beijing, China

13 Corresponding Author: Zhongli Sha

14 Email address: shazl@qdio.ac.cn

Abstract Macromedaeus is one of the most common xanthid genera in shallow waters of the Indo-West Pacific. In this study, we describe a new species, Macromedaeus hainanensis sp. nov., and report on two newly recorded species, M. quinquedentatus (Krauss, 1843) and M. orientalis (Takeda \& Miyake, 1969) from Hainan Island, South China Sea. M. hainanensis is most related to M. distinguendus (De Haan, 1835) and M. orientalis on the carapace shape and granular appearance, but can be distinguished by unique morphological characteristics especially its front, pereopods and male first gonopod. Taxonomic identities of the six Macromedaeus species recorded from China seas are discussed, and a phylogenetic analyzation is performed on 
23

24

25

26

27

Macromedaeus and related taxa based on three mitochondrial and two nuclear markers $(12 \mathrm{~S}, 16 \mathrm{~S}$, COI, H3, 18S). Integrated taxonomic evidence is used to support the taxonomic status of each species.

\section{Introduction}

The xanthid crab genus Macromedaeus Ward, 1942 currently includes six described species found from the Indo-West Pacific are often common and abundant members in intertidal fauna of rocky seashores $(\mathrm{Ng}, 2008)$. The genus was established with M. punctatus Ward, 1942 as the type species, and he also attached Xantho nudipes A. Milne Edwards, 1867 to Macromedaeus. However, M. punctatus was considered synonymous with $M$. nudipes for the slight differences, and now M. nudipes is taken as the type species of Macromedaeus (Ward, 1942; Guinot, 1968; 1971; Serène, 1984).

Guinot (1968) transferred five species from Xantho Leach, 1814 or Leptodius A. MilneEdwards, 1863 to Macromedaeus. Macromedaeus differs from its most related genus Leptodius by: antennary basal segment stout and straight in Macromedaeus, while it slender and inclined in Leptodius; antennular fossa straighter and shorter in Leptodius; third maxillipeds stouter, merus with a protruding external angle in Leptodius and the first gonopod of male (G1) of Macromedaeus having a stout apical lobe, while in Leptodius the G1 having a slender apical lobe with prominent mushroom-like or tongue-like extensions (Guinot, 1968).

Macromedaeus currently consists of six species: M. crassimanus (A. Milne-Edwards, 1867), M. demani (Odhner, 1925), M. distinguendus (De Haan, 1835), M. nudipes (A. Milne-Edwards, 1867), M. quinquedentatus (Krauss, 1843) and M. voeltzkowi (Lenz, 1905) (Ng, 2008), and three of them (M. distinguendus, M. crassimanus and M. demani) have been reported from China seas (Liu, 2008). Microcassiope orientalis Takeda \& Miyake, 1969 should be transformed into Macromedaeus (Yamaguchi et al., 1976; Takeda, 1977; Maenosono, 2021), but this suggestion was not accepted widely $(\mathrm{Ng}, 2008$; Lee, 2012). 
48

49

50

During a recent collection from Hainan Island, several individuals referable to Macromedaeus were collected. Some of them exhibit distinctive characters differentiating them from other described Macromedaeus species, so they are identified as a new species herein. $M$. quinquedentatus is newly recorded from China seas. Additionally, Microcassiope orientalis is also founded from China seas firstly. A review of Macromedaeus is performed using integrative taxonomy methods, and an identification key for Macromedaeus species is provided.

\section{Materials and methods}

The specimens were collected from China Seas by intertidal collections from 1950 to 2020 . They were stored in 70\% ethanol and deposited in the Marine Biological Museum, Chinese Academy of Sciences (MBMCAS), Qingdao, China.

Morphological characteristics were observed using ZEISS Stemi 2000-c and ZEISS Stemi SV 11 Apo stereo microscope, and Nikon Eclipse Ci-L microscope. Photographs were taken using Canon EOS 6D camera with Canon EF 100mm and Canon MP-E 65mm lens or using Nikon D800 camera with Nikon AF-S 105mm lens.

The morphological terms followed that used by Dana (1852) and Serène (1984), and the following abbreviations were used in the text: CW (maximum carapace width); CL (median carapace length); ab1-6 (abdominal somites 1-6); st1-8 (thoracic sternites 1-8); P1-5 (pereopods 1-5); G1 (first gonopod of male); G2 (second gonopod of male); 1-2F (frontal regions 1-2); 1-4M (medial regions 1-4); 1-6L (antero-lateral regions 1-6); 1-3R (postero-lateral regions 1-3); 1-2P (posterior regions 1-2).

Molecular phylogenetic analyses were performed on Macromedaeus species and related taxa to understand their phylogenetic position. Genomic DNA was extracted from muscle tissue using the OMEGA EZNA Tissue DNA Kit (USA) following the manufacturer's protocol. Molecular characters were obtained from three mitochondrial and two nuclear markers, which were mitochondrial 12S rRNA (12S, approximately 363bp), 16S rRNA (16S, approximately 521bp), 
73

74

cytochrome oxidase I (COI, approximately 658bp), nuclear histone H3 (H3, approximately 328bp) and $18 \mathrm{~S}$ rRNA (18S, approximately 644bp). Markers were amplified via polymerase chain reaction (PCR) with primers 12sf and 12s1r for 12S (Buhay et al., 2007), 16Sar and 16Sbr for 16S (Palumbi, 1996), dgLCO-1490 and dgHCO-2198 for COI (Meyer, 2003), 18S-B and 18S-O for 18S (Medlin et al., 1988; Apakupakul, Siddall \& Burreson, 1999), and Hex-AF and Hex-AR for H3 (Svenson \& Whiting, 2004).

PCR was performed in $25 \mu \mathrm{l}$ volumes containing: $1 \mu \mathrm{l}$ (3-200 ng) of genomic DNA as template, $1 \mu \mathrm{l}(10 \mathrm{pM})$ of each primer, $12 \mu \mathrm{l}$ of $2 \times$ PCR Mix (Dongsheng Biotech, Guangzhou, China) and $10 \mu \mathrm{l}$ ultrapure water. Reactions were carried out as following steps: initial denaturation at $95{ }^{\circ} \mathrm{C}$ for $5 \mathrm{~min} ; 35$ cycles for denaturation at $95{ }^{\circ} \mathrm{C}$ for $30 \mathrm{~s}$, annealing at $60{ }^{\circ} \mathrm{C}(12 \mathrm{~S}), 48{ }^{\circ} \mathrm{C}$ (16S), $58{ }^{\circ} \mathrm{C}(18 \mathrm{~S}), 48{ }^{\circ} \mathrm{C}(\mathrm{COI}), 66{ }^{\circ} \mathrm{C}(\mathrm{H} 3)$ for $45 \mathrm{~s}$, extension at $72{ }^{\circ} \mathrm{C}$ for $45 \mathrm{~s}$, and final extension at $72{ }^{\circ} \mathrm{C}$ for $10 \mathrm{~min}$.

The obtained sequences were edited using Lasergene and aligned by MEGA version 6 (Tamura et al., 2013). Alignments were concatenated by SequenceMatrix 1.8 (Vaidya et al. 2011). In the final dataset, including gaps, there were total $363 \mathrm{bp}$ for the $12 \mathrm{~S}, 534 \mathrm{bp}$ for the $16 \mathrm{~S}, 499 \mathrm{bp}$ for the 18S, $524 \mathrm{bp}$ for the COI and 306 for $\mathrm{H} 3$ dataset.

Maximum Likelihood (ML) and Bayesian Inference (BI) analyses were implemented in phylogenetic studies. The best-fit model of evolution for each dataset was identified using jModeltest 0.1.1 under the Akaike information criterion (AIC) (Posoda, 2008). BI analyses were carried out using MrBayes 3.2.7 (Huelsenbeck \& Ronquist, 2001). A Markov ChainMonte Carlo (MCMC) algorithm with two runs of four chains each was run for 1,000,000 generations with trees sampled every 500 generations (2000 trees sampled). The first 500 trees were discarded and the posterior probabilities were estimated for the remaining samples. The ML analyses were performed online at W-IQ-TREE (Jana et al., 2016). Clade support was assessed with 1,000 ML bootstrap replications. The genetic divergences of COI between and within the Macromedaeus species were constructed in MEGA version 6 (Tamura et al., 2013). 
99 100 101

The electronic version of this article in Portable Document Format (PDF) will represent a published work according to the International Commission on Zoological Nomenclature (ICZN), and hence the new names contained in the electronic version are effectively published under that Code from the electronic edition alone. This published work and the nomenclatural acts it contains have been registered in ZooBank, the online registration system for the ICZN. The ZooBank LSIDs (Life Science Identifiers) can be resolved and the associated information viewed through any standard web browser by appending the LSID to the prefix http://zoobank.org/. The LSID for this publication is: [urn:lsid:zoobank.org:pub:07834F78-CD9D-4516-A92C-7FC5B680A7F9] The online version of this work is archived and available from the following digital repositories: PeerJ, PubMed Central SCIE and CLOCKSS.

\section{Results}

\section{Taxonomy}

Family Xanthidae MacLeay, 1838

Subfamily Xanthinae MacLeay, 1838

Genus Macromedaeus Ward, 1942

\section{Macromedaeus hainanensis sp. nov.}

\section{Material examined}

Type material. Holotype. 1 male $(6.54 \times 4.34 \mathrm{~mm})$; Nov. 12, 2016; Mulan Bay, Wenchang, Hainan, Junlong Zhang, Yang Li, Shuqian Zhang et al. coll. (MBM286988). Paratypes. 1 female (14.69×9.21 mm); Nov. 3, 1990; Qukou, Haikou, Hainan (MBM160965); 1 female; Nov. 12, 2016; Mulan Bay, Wenchang, Hainan; Junlong Zhang, Yang Li, Shuqian Zhang et al. coll. (MBM286989) ; 1 female (6.94×4.54 mm); Nov. 12, 2016; Mulan Bay, Wenchang, Hainan; Junlong Zhang et al. coll. (MBM286990); 1 male $(7.14 \times 4.86 \mathrm{~mm}), 2$ females $(5.02 \times 3.39 \mathrm{~mm}$; 4.44×3.35 mm); Nov. 12, 2016; Mulan Bay, Wenchang, Hainan, Junlong Zhang et al. coll. 
123

124

125

126

127

128

129

130

131

132

133

134

135

136

(MBM286991); 1 male (7.56 $\times 4.75$ mm); Nov. 29, 2007; Linchang Reef, Hainan, Xianqiu Ren coll. (MBM282500); 2 females $(9.44 \times 5.99$ mm, 5.53×3.78mm); Apr. 13, 2008; Linchang Reef, Danzhou, Hainan; Wei Jiang, Yang Li coll. (MBM286992).

\section{Description of the holotype.}

Carapace (Fig. 1A, B, 2A) transversely ovate, width about 1.5 times length, dorsal slightly convex; dorsal surface covered with granules, more or less arranged in lines; regions well defined in anterior $2 / 3$, especially $2 \mathrm{M}, 3 \mathrm{M}, 5 \mathrm{~L}$ and $6 \mathrm{~L}$, subhepatic and pterygostomian regions (Fig.1C) granular. Front (Fig. 1B, 2C) double-rimmed, both granular, not produced, slightly deflexed, about 0.3 times carapace width, divided into 2 lobes by a $\mathrm{v}$-shape mesial notch, margin of frontal lobes nearly straight, external part advanced. Anterolateral border convex, divided into 4 teeth except exorbital angle, separated from each other by wide v-shape notches, first low, triangular, not advanced, second widest, anterior margin shorter than posterior, third most advanced, anterior margin shorter than posterior, fourth small but distinct. Posterolateral margin slightly longer than anterolateral margin. Posterior margin slightly convex.

Orbits suboval (Fig. 1B, 2A), orbital region granular; supraorbital margin with 2 fissures, dorsal inner orbital angle separated from front by a deep notch; infraorbital tooth blunt. Eyestalk stout, covered with granules. Antennular fossae subrectanglar; antennules folding transversely. Basal segment of antenna subrectanglar, flagellum entering orbital hiatus, tip reaching exorbital angle. Epistome broad, posterior margin with a low and blunt mesial prominence. Endostome with oblique ridges posteriorly.

Third maxillipeds (Fig. 1C, 2B) completely covering buccal orifice; merus subquadrate, granular, anterolateral angle slightly produced; ischium subrectangular, about 2 times as long as merus, surface nearly smooth, sulcate submedially; exopod broad, subdistal portion with a rounded projection beneath inner margin.

Male thoracic sternum (Fig. 1D) slightly granular, st1, 2 fused, suture between st2, 3 distinct, 
148 backward convex; st 3 and 4 almost fused, suture only present on lateral edges, and continue by a 149 feeble but visible transverse depression in middle part; st4 broad, with a distinct median 150 longitudinal groove; press-button on posterior of st5.

151

152

Chelipeds (Fig. 1E, F) unequal, robust; merus short, with setae on inner edge; carpus robust, with granules and finely areoles on dorsal surface, internal angle blunt; palm uniform granular, with a groove on outer surface near dorsal; fingers short and robust, brown pigmented, nearly not extent to palm, cutting margins with 4 blunt teeth on both fingers, an enlarged blunt tooth on dactylus subbasal part of large cheliped; dactylus shorter than superior margin of palm, with 2 dorsal longitudinal grooves; fixed finger with 2 granular lines on outer surface; finger tips spoonshaped, with a tuft of setae.

Ambulatory legs (Fig. 1A, 2E) short, slightly depressed, edges with long setae, P3 and P4 longest, P5 (Fig. 2E) shortest; merus with granules on dorsal surface; carpus curved, covered with granules; propodus subrhombic, with granules; dactylus with spiny granules and setae, a sharp and strong subterminal tooth on dactylus posterior margin of the last 3 ambulatory legs, larger on posterior dactylus, tip claw-shaped; dactylo-propodal articulation with distinct lock composed of rounded prolongation on propodus distal lateral margin sliding against prominent button on dactylus proximal lateral margin; P5 dactylus tip nearly straight, slightly forward pointed.

Male abdomen (Fig. 1D, 2D) with ab1 and ab2 broad, subtrapezoidal; ab3-5 completed fused; ab6 subquadrate, width slightly larger than length, enlarger on subdistal; telson subtriangular, angles rounded, basal width slightly larger than median length.

G1 (Fig. 2F, G, I) long and slender, slightly curving laterally; distal tip with a sharp and elongate apical lobe wrapping the subdistal lobe; subdistal part with about 17 subterminal spines, distal 6 of them on the prominent subdistal lobe; outer ventral surface of subdistal part with little spines. G2 slightly sigmoidal in shape, about 1/4 length of G1.

Female morphology. The female (Fig. 3) is similar to male in morphology generally, but 
173 there are still some differences. The largest female specimen shows a more prominent and 174 narrower front (front about 0.27 times $\mathrm{CW} ; 0.3$ times in the male holotype) and a wider carapace $175(\mathrm{CW} / \mathrm{CL}=1.6 ; 1.5$ in the male holotype) (Fig. 3A, B) compared with the male holotype which 176 may be caused by the growth of the individuals. In females, the abdomen (Fig. 3D) is wider and

177 178 oval with seta on the margin, and pleonal somites not fused. The chelipeds (Fig. 3E, F) are equal, and palms are slender.

Etymology. The species is named after its type locality, Hainan Island, Hainan province, China.

Distribution. Presently only known from the type locality, Hainan Island.

Remarks. Macromedaeus hainanensis sp. nov. is most similar to M. distinguendus for having four triangular anterolateral teeth and granular carapace and to M. orientalis for having smaller body size and the same front.

M. hainanensis sp. nov. differs from $M$. distinguendus by: carapace more granular, regions relatively flat, with granular lines but not form produced crests (carapace regions more prominent, with obvious granular crests in $M$. distinguendus); anterolateral teeth narrower, apices more projecting, forming an acute angle (anterolateral teeth broader, apices slightly projecting, forming an obtuse angle in $M$. distinguendus); the front double-rimmed, at least 0.27 times $\mathrm{CW}$, not produced, margin of frontal lobes nearly straight (not double-rimmed, about 0.22 times CW, produced, margin leaning in M. distinguendus); ambulatory legs carpus without distinct crest, dactylus with a strong subterminal tooth in the last 3 legs. (carpus with 3 crests, dactylus without distinct subterminal tooth in M. distinguendus); P5 dactylus tip nearly straight, slightly pointed forward (P5 dactylus tip curved backward in M. distinguendus); G1 stout with a sharp and elongate apical lobe, subdistal lobe short, with 6 curving spines on the prominent lube. (G1 slender, with blunt apical lobe, subdistal lobe longer, with about 11 curving spines on the prominent lube in $M$. distinguendus) and $M$. hainanensis sp. nov. obviously smaller than the latter (the largest specimens of M. hainanensis sp. nov. having a $14.69 \mathrm{~mm} \mathrm{CW}$, and the largest $M$. distinguendus having 30.58 
$\mathrm{mm} \mathrm{CW}$ ).

M. hainanensis sp. nov. differs from $M$. orientalis by: P5 stout, dactylus tip nearly straight, slightly pointed forward (P5 slender, propodus and dactylus prolonged, with a longer dactylus tip curved backward in M. orientalis); chelipeds palm outer surface with denser granules, more uniform in size (it with sparser but more prominent granules, the larger one with 2 longitudinal grainy lines in M. orientalis); unmoved finger of male chelipeds with brown color nearly not spread to palm. (it spread to palm inner and outer surface in M. orientalis); G1 slender, apical lobe not upturned, the ventral rim more prominent than the dorsal rim (G1 stout, apical lobe slightly upturned, the dorsal rim more prominent than the ventral rim in M. orientalis).

\section{Macromedaeus orientalis (Takeda \& Miyake, 1969)}

Microcassiope orientalis Takeda \& Miyake, 1969: 202-205, figs. 2, 3; Ng, 2008: 203 (list); Lee, 2012: 160-164, figs. 122-124.

Macromedaeus orientalis Yamaguchi et al., 1976: 37, fig. 2; Takeda, 1977: 84; Lee \& Ko, 2008: 17-19, fig. 1; Maenosono, 2021: 10, figs. 1h-i, figs. 7a-f, fig. 8f.

Material examined: 1 female; Nov. 21; 2016, Hainan, subtidal zone 9-10m; Junlong Zhang coll, (MBM286993); 2 males; Mar. 19, 1992; Hainan (MBM286994); 1 female, Nov. 20, 1990; Yalong Bay, Sanya, Hainan (MBM164388); 1male; Nov. 20, 1990; Yalong Bay, Sanya, Hainan, (MBM164386).

\section{Size. CW: $5.20-8.14 \mathrm{~mm}, \mathrm{CL}: 3.47-5.23 \mathrm{~mm}$.}

Diagnosis. Carapace (Fig. 4A, B) transversely ovate, the breadth is about 1.5 times the length; regions well-defined on anterior $2 / 3$, covered with granules and form rows of transverse line; inner and outer lobules of $2 \mathrm{M}$, the anterior edge of $5 \mathrm{~L}$ and inner angle of $6 \mathrm{Lwith}$ a tuft of brush-like setae respectively. Front (Fig. 5A) about 1/3 the breadth of carapace, not produced, doublerimmed, both granular, divided into 2 lobes by a v-shape notch, margin of frontal lobes rounded. 
223

224

225

226

227

228

229

230

231

232

233

234

235

236

237

238

239

240

241

242

243

244

245

246

247

supraorbital margin with 2 fissures. Anterolateral border armed with 4 teeth except the outer orbital angle, the second tooth largest. Posterolateral border subequal with anterolateral border. Lateral surface of carapace clothed with setae. Antennule situated transversely; orbital hiatus filled by antennal flagellum. Third maxilliped (Fig. 4C) completely covering buccal orifice; merus subquadrate, granulated; ischium subrectangular, with a smooth groove. Thoracic sternites (Fig. 4D) smooth; the suture between st1-2 and 3 distinct, backward convex, the median line of st4 distinct.

Chelipeds (Fig. 4E, F) unequal; merus with granules on outer surface and setae on inner edge; carpus armed with a tooth on inner angle, dorsal surface with granules and tubercles; palm covered with sharp granules, more prominent on the smaller cheliped, the large cheliped with 2 longitudinal grainy lines; fingers black brown, the color of fixed finger extend to palm irregularly in male; dactylus with 2 longitudinal dorsal grooves, cutting edges of the large cheliped with 4 blunt tooth; finger tips spoon-shaped, with a tuft of setae.

Ambulatory legs (Fig. 4A, 6A) with sharp granular, edges with long setae; dactylus armed with spiny granules and setae, tip claw-shaped; a sharp subterminal tooth on dactylus posterior margin of the last 3 ambulatory legs, larger on posterior dactylus; dactylo-propodal articulation with distinct lock composed of rounded prolongation on propodus distal lateral margin sliding against enlarged prominent button on dactylus proximal lateral margin; P5 (Fig. 6A) slender, propodus and dactylus prolonged, dactylus tip prolonged, curved backward.

Abdominal somites (Fig. 4D) 3-5 completely fused in male. G1 (Fig. 7A, E, I) stout, slightly curving laterally; distal tip with a apical lobe slightly upturned on the tip and wrapping the subdistal lobe, the apical lobe dorsal rim more prominent than the ventral rim; subdistal part with about 16 curving subterminal spines, distal 5 on the prominent subdistal lobe; outer ventral surface of subdistal part with little spines.

Type locality. Munakata-Oshima Islet, Fukuoka Prefecture, Japan. 
Distribution. Hainan Island; southeast of Korea, Japan.

249

250

251

252

253

254

255

Remarks: M. orientalis was first referred to Microcassiope Guinot, 1967. Yamaguchi et al. (1976) suggested that the species should be transferred to Macromedaeus Ward, 1942, but $\mathrm{Ng}$ et al. (2008) and Lee (2012) still listed the species under Microcassiope. M. orientalis is listed under Macromedaeus in present study for M. orientalis sharing similar G1 apical structure with other Macromedaeus species that the apical lobe wrapping the subdistal lobe; chelipeds of M. orientalis have blunt and concave finger tips like other Macromedaeus species, while species of Microcassiope have more sharp and curving finger tips (Guinot, 1967).

M. orientalis was firstly reported from China seas herein. The present specimens show some variations compared with previous descriptions in the following two characters: the front less prominent; G1 with an apical lobe slightly upturned on the tip and wrapping the subdistal lobe, ventral rim slightly lower than the dorsal rim (Takeda \& Miyake, 1969; Yamaguchi et al., 1976; Lee \& Ko, 2008; Lee, 2012; Maenosono, 2021).

M. orientalis is similar to M. distinguendus. M. orientalis differs from M. distinguendus by: smaller size; carapace rougher; front double-rimmed and divided into two lobes by a wide v-shape mesial notch deeply; anterolateral teeth narrower, apices more projecting; P5 slender, especially the propodus and dactylus, dactylus armed with a larger subterminal tooth, tip prolonged and curved backward and G1 apical lobe dorsal rim more prominent than the ventral rim (Takeda, 1977; Maenosono, 2021).

\section{Macromedaeus distinguendus (De Haan, 1835)}

Cancer (Xantho) distinguendus De haan, 1835: 48, pl. 13, fig. 7.

Xantho distinguendus Alcock, 1898: 113 (part); Sakai, 1939: 461, pl. 58, fig. 4, pl. 191, fig.4; Shen, 1932, 97, figs. 56, 58a, b, pl. 2, fig. 5; Gordon, 1931: 543, figs. 21, 22c; Forest \& Guinot, 1961: 57, fig.46; Buitendijk, 1960: 330; Sendler, 1923: 37. 
272

273

274

275

276

277

278

279

280

281

282

283

284

285

286

287

288

289

290

291

292

293

Xanthodius distinguendus Balss, 1922: 6.

Chlorodius distinguendus Stimpson, 1858: 34.

Medaeus distinguendus de Man, 1887: 31.

Leptodius distinguendus Rathbun, 1931: 100.

Macromedaeus distinguendus Guinot, 1968: 708; Sakai, 1976: 419, fig. 221, pl. 153, fig. 2;

Dai et al., 1968: 265, fig. 151-1; 1991: 286, fig. 151-1, pl. 36, fig. 5; Kim, 1973: 379, fig. 143, pl.

27, fig. 108; Serène, 1984: 177 (keys); Lee, 2012: 154, figs. 118-120; Ho et al., 2000: 114 (list);

Ng et al. 2001: 25 (list); Ng et al. 2007: 93 (list); Liu 2008: 797 (list).

Non Xantho distinguendus Heller, 1861: 323; Alcock, 1898: 113 (part); Nobili, 1906: 239;

Laurie, 1906: 401; Klunzinger, 1913: 200 (part); Stebbing, 1918: 51.

= Medaeops neglectus (Balss, 1922).

Non Xantho distinguendus Klunzinger, 1913: 203 (part), pl. 5, fig. 7.

= Danielea noelensis (Ward, 1935).

Non Medaeus distinguendus Henderson, 1893: 359.

= Medaeops neglectus (Balss, 1922).

\section{Material examined}

1 male, 1 female; May. 8, 2010; Sanniang Bay, Qinzhou, Guangxi; Haiyan Wang et al. coll. (135CC03764); 2 males; Oct. 1, 2019; Lingshan Island, Qingdao, Shandong; Weiwei Xian coll. (MBM286999,); 1male; May. 6, 2010; Hepu, Guangxi; Haiyan Wang et al. coll. (135CC03752); 1 male, May. 1, 2010; Shankou, Beihai, Guangxi, Haiyan Wang et al. coll. (135CC03760); 6 males, 6 females, Apr. 19, 2019; Rushan, Weihai, Shandong (MBM2867000); 5 males, 1 female; Jan. 27, 1951; Huiquan Bay, Qingdao, Shandong (MBM160961); 2 males; Sep. 16, 1955; Qingdao, 
294 Shandong (MBM160929); 2 males, 1 female; May. 21, 1963; Daheilan, Qingdao, Shandong; 295 Xiubin Fang coll. (MBM160931); 2 males; May. 14, 1950; Qingdao, Shandong; (MBM160928); 2961 male; Jul. 14, 1955; Zhonggang, Qingdao, Shandong; Zhengang Fan coll. (MBM160936); 8 297 males, 7 females, Dec. 25, 1950; east of Taipingjiao, Qingdao, Shandong; Xiuji Zhang coll. 298 (MBM160926); 2 males; Aug. 14, 1957; Qingdao, Shandong; Yiqian Liu coll. (MBM160966); 2

299 300 301 302 303 304 305 306 307 308 309 310 311 312 males, 4 females; Sep. 22, 1955; Cangkou, Qingdao, Shandong, (MBM160940); 10 males, 6 females; Apr. 29, 1950; Qingdao, Shandong; Xiuji Zhang coll. (MBM160953); 1 male, 1 female ovigerous; Aug. 21, 1959; Zhonggang, Qingdao, Shandong; Zhongyan Qi, YongliangWang et al. coll. (MBM160941); 7 males, 1 females ovigerous; Sep. 19, 1963; Daheilan, Qingdao, Shandong; Zhengang Fan et al. coll. (MBM160960); 1 male; Feb, 7, 1964; Huangdao, Qingdao, Shandong; Zhengang Fan et al. coll. (MBM160921); 1 male; Mar. 16, 1981; Hongshian, Qingdao, Shandong, Xianqiu Ren coll. (MBM160935); 2 females; Sep. 5, 1962; Zhonggang, Qingdao, Shandong (MBM160956); 14 males, 6 females; Oct. 4, 1979; Pingyang, Zhejiang; Xianqiu Ren coll. (MBM160943); 2 males, 2 females; Daheilan, Qingdao, Shandong, Zhengang Fan, Jieshan Xu coll. (MBM160942); 1 male; Nov. 17, 1963; Daheilan, Qingdao, Shandong; Zhengang Fan, Jieshan Xu coll. (MBM160946,); 8 males, 5 female; Oct. 21, 1963; Daheilan, Qingdao, Shandong; Zhengang Fan et al. coll. (MBM160945); 1 male, 1 female; Nov. 2, 1956; Qingdao, Shandong; Zhengang Fan, Jieshan Xu coll. (MBM160939); 2 male; May. 22, 1951; Daheilan, Qingdao, Shandong; Xiuji Zhang coll. (MBM160923); 3 males; 2 females; Jun. 21, 1963; Daheilan, Qingdao, Shandong; Zhengang Fan coll. (MBM160938); 1 male, 1 female; Dec. 18, 1952; Qingdao, Shandong; Xiuji Zhang coll. (MBM160955); 2 males, 2 females; Aug. 24, 1980; Hongshian, Qingdao, Shandong (MBM160933); 1 male; Jul. 31, 1957; Taipingjiao, Qingdao, Shandong (MBM160927); 1 male; 1 female; May. 22, 1963; Changkou, Qingdao, Shandong; Xianqiu Ren, Xiubin Fang coll. (MBM160934); 2 males, 3 females; Sep. 9, 1983; Shijiusuo, Rizhao, Shandong (MBM160951); 1 male, 1 female; May. 25, 1975; Dongshan, Fujian; Mu Chen coll. (MBM160920); 3 males, 3 females; May. 29, 1957; Maidao, Qingdao, Shandong; Yiqian Liu coll. (MBM160959); 2 males, Oct. 4, 1979; Pingyang, Zhejiang (MBM160958); 1 female; Sep. 
321 16, 1956; Qingdao, Shandong; (MBM160947); 1 male, 2 females; May. 31, 1957; Daheilan, 322 Qingdao, Shandong; Jieshan Xu coll. (MBM160962); 1 female; Sep. 7, 1956; Maidao, Qingdao, 323 Shandong; Zhengang Fan, Xiuji Zhang coll. (MBM160952); 1female; Sep. 18, 1951; Qingdao, 324 Shandong (MBM160957); 8 males, 1female; Sep. 16, 1955; Qingdao, Shandong (MBM160925); 3255 males, 3 females; Dec. 14, 1955; Daheilan, Qingdao, Shandong (MBM160954).

Size: CW: 6.74-30.58mm, CL: 4.91-19.58mm.

327

328

Diagnosis: Carapace (Fig. 8A, B) hexagonal, the breadth is about 1.5 times the length; dorsal surface granular, arranged in ridgy lines and crest; anterior $2 / 3$ well defined, regions rise; front (Fig. 8B, 5B, C) narrow, about $1 / 4$ the breadth of carapace, produced, edge grainy and oblique, middle produced, divided by a narrow crack. Dorsal orbital edge with double cracks, eyestalk with granules near the dorsal proximal border of cornea. anterolateral border armed with 5 teeth except the outer orbital angle; the first tooth small; second and third broad, with an acute tip; the last tooth triangular. posterolateral border shorter than anterolateral border, slightly concave. Lateral surface of carapace with setae. Antennule situated transversely; orbital hiatus filled by antennal flagellum. Third maxilliped (Fig. 8C) completely covering buccal orifice; merus subquadrate, granulated; ischium subrectangular, with a smooth groove. Male thoracic sternites (Fig. 8D) smoother; groove between st1-2 and 3 slightly bending, median line of st 4 deep.

Chelipeds (Fig. 8E, F) unequal; merus with setae on inner edge; carpus with a blunt tooth on inner angle, dorsal surface with irregular areoles and protuberances; palm covered with granules, irregular tubercles on dorsal outer surface; fingers black brown, the color of fixed finger extend to palm irregularly in male; dactylus with a central ridge and 2 longitudinal dorsal grooves, cutting edges with 4 blunt teeth; finger tips spoon-shaped.

Ambulatory legs (Fig. 8A, 6B) granular; merus anterior edges clothed with setae; carpus armed with 3 wavy protuberances on anterior edges, dactylus with spiny granules and setae, tip claw-shaped; posterior margin with spiny granules, without obvious subterminal tooth; dactylo- 
347 propodal articulation with lock composed of rounded prolongation on propodus distal lateral 348 margin sliding against button on dactylus proximal lateral margin; P5 dactylus tip short, curved 349 backward.

350

351

352

353

354

355

356

357

358

359

360

361

362

363

364

365

366

367

368

369

370

Abdominal somites (Fig. 8D) 3-5 completely fused in male; G1 (Fig. 7B, F, J) long and slender, slightly curving laterally; distal tip with an apical lobe wrapping the subdistal lobe; subdistal part with subterminal spines curve to dorsal, distal 11 of them on the prominent subdistal lobe; outer ventral surface of subdistal part with little spines.

Living color is shown in Figure 9.

Type locality. Japan.

Distribution. Coast of China: Guangxi, Guangdong, Fujian, Taiwan, Zhejiang, Shandong Peninsula, Bohai Gulf; Mergui Archipelago, Korea, Japan, Tahiti, Palau.

Remarks: $M$. distinguendus is widely distributed along the coast of China. This species shows perceptible variations especially on: the granular crests on carapace, from low to rose; chelipeds dorsal surface of palm and carpus, from granular areolar to tubercular; anterolateral border teeth, from low and wide trilateral to prominent with sharp tip; the front divided by a narrow crack, or by a v-shape notch (Fig. 5B, C, 10). Those variations were identified as intraspecific.

The specimens identified by Alcock (1898), Heller (1861), Nobili (1906), Klunzingeru (1913), Laurie (1906) and Stebbing (1918) as M. distinguendus are actually Medaeops neglectus (Balss, 1922) (Balss, 1922; 1924; Guinot,1967), meanwhile other specimens identified by Klunzingeru (1913) as M. distinguendus are actually Danielea noelensis (Ward, 1935) (forest \& Guinot, 1961). Compared with Medaeops neglectus, M. distinguendus has chelipeds with spoonshaped finger tips, and has distinct G1 morphology (Balss, 1922; 1924; Odhner, 1925; Gordon, 1931; Forest \& Guinot 1961). 
M. distinguendus is similar with M. hainanensis sp. nov and M. orientalis. Diagnoses have

372

373

374

375

376

377

378

379

380

381

382

383

384

385

386

387

388

389

390

391

392

been discussed in remarks of the latter two.

\section{Macromedaeus quinquedentatus (Krauss, 1843)}

Cancer (Xantho) 5-dentatus Krauss, 1843: 30, pl. 1 figs. 3 a-d.

Xantho (Leptodius) euglyptus Alcock, 1898: 121.

Xantho (Leptodius) quinquedentatus Barnard, 1950: 225, figs. 42f-g.

Xantho quinquedentatus Buitendijk, 1960: 321, figs. 9g-i.

Leptodius euglyptus Alcock, 1899: pl. 36 fig. 1.

Leptodius euglyptus quadrispinosus Chhapgar, 1957: 429, pl. 9 d-f.

Macromedaeus quinquedentatus Guinot, 1968: 708; Serène, 1984: 177 (keys), 179, fig. 104, pl. XXV D-E; Galil \& Vannini, 1990: 40; Apel, 2001: 87; Mendoza et al., 2014: 284;

Ghotbeddin \& Naderloo, 2014: 3, fig. 2b; Naderloo, 2017: 258, figs. 21, 32; Maenosono, 2021:

4, figs. 1b-c, figs. 3a-g, fig. 8 b.

Non Xantho quinquedentatus Edmonson, 1962, 239, fig. 6d.

\section{Material examined}

2male; Mar. 23, 2008; Xiaodonghai, Hainan; Wei Jiang coll. (MBM282511); 1 male, 1 female; Dec. 24, 2007; Xiaodonghai, Hainan (MBM286995); 1 male; Dec. 25, 2007; Hainan; Wei Jiang coll. (MBM286996); 2 males; Jul. 5-6, 2020; Sanya, Hainan; Yunhao Pan, Fei Meng coll. (MBM286997); 1 male, 1 female; Nov. 11, 1990; Xiaodonghai, Hainan (MBM160944).

Size: CW: 5.84-24.77mm, CL: 3.94-15.60mm.

Diagnosis: Carapace (Fig. 11A, B) hexagonal, the breadth is about 1.5 times the length; dorsal surface finely granular; anterior $2 / 3$ well-defined by broad and deep grooves. Front (Fig. 
393

394

395

396

397

398

399

400

401

402

403

404

405

406

407

408

409

410

411

412

413

414

415

416

417

418

5D) narrow, about 1/5 the breadth of carapace, produced, divided into 2 lobes by a v-shape notch, edge grainy and sinuous, outer lobes wide and prominent, make a 4-lobes look. Dorsal orbital edge with double cracks, eyestalk with granules near the dorsal proximal border of cornea. anterolateral border armed with 5 teeth except the outer orbital angle; the first tooth blunt; second to fourth tooth about equal; the last tooth small. Posterolateral border concave, shorter than anterolatera. Setae present on lateral surface of carapace. Antennule situated transversely; antennal flagellum filling the orbital hiatus. Third maxilliped (Fig. 11C) completely covering the buccal orifice; merus subquadrate, granulated, with anterolateral angle produced; ischium subrectangular, with a groove. Male thoracic sternites (Fig. 11D) smooth, with sporadic granules; groove between st1-2 and 3 bending, st 4 median line deep.

Chelipeds (Fig. 11E, F) unequal; merus inner edge with setae; carpus with an inner angle tooth, dorsal surface with irregular areoles and granules; palm prolonged, dorsal and outer surface covered with granules and tubercles, inner and ventral surface smooth; fingers black brown, in male individuals the color of fixed fingers extending to palm irregularly; dactylus curving, dorsal surface with double grooves, cutting edges with 4 triangular teeth; finger tips spoon-shaped.

Ambulatory legs (Fig. 11A, 6C) granular; merus anterior edges clothed with setae; carpus armed with 3 wavy protuberances on anterior edges; dactylus with spiny granules and setae, tip claw-shaped; sharp subterminal tooth present on dactylus posterior margin of the last 2 ambulatory legs in smaller individuals, only with granules in larger individuals; dactylo-propodal articulation with underdeveloped lock composed of rounded prolongation on propodus distal lateral margin sliding against lower button on dactylus proximal lateral margin; P5 dactylus tip curved backward. 
419 subdistal lobe; outer ventral surface of subdistal part with little spines; apical lobe with 5-16 420 sawtooth-like extensions on ventral brim.

Type locality. Natal bay, South Africa.

422

423

424

Distribution. Hainan Island; South Africa, Mozambique, Madagascar, Somalia, Golf of Aden, Dhofar, Gulf of Oman, Pakistan, India, Sri Lanka, Myanmar, Sulawesi Island, Flores Islands, Soela Islands, Talaud Islands, Timor Island, Misool Island, New Guinea, Okinawa.

Remarks. M. quinquedentatus is newly recorded from China seas. G1 of the species with some degree of variation on the apical lobe length and sawtooth-like extensions number. In the present materials, the number of extensions is from 5 to 16 and the larger species generally have longer apical lobes and more extensions. Similar variations have been figured by Buitendijk (1960).

The species is most related to M. crassimanus (A. Milne-Edwards, 1867) for having five anterolateral teeth and a sinuous front. M. quinquedentatus can be distinguished from $M$. crassimanus by: surface of carapace, chelipeds, ambulatory legs and third maxilliped with obvious granules, carapace slightly convex (surface with fine granules, carapace obvious conves in $M$. crassimanus); fronto-orbital wide, only slightly less than half of the $\mathrm{CW}$ (fronto-orbital narrow, distinctly less than half the $\mathrm{CW}$ in $M$. crassimanus); carapace regions with areolae sharp, separated by large deep grooves (regions slightly projecting, separated by broad and shallow furrows in M. crassimanus); chelipeds palm armed with four prominent tubercles on superoexternal margin and with two longitudinal granulate ridges on external surface (only with rugose on superoexternal margin and a smoother external surface in $M$. crassimanus); G1 having a long apical lobe with more than five developed t extensions (G1having a short apical lobe, with 2 very low extensions in M. crassimanus)(Buitendijk, 1960; Serène, 1984; Mendoza, 2014; Maenosono, 2021). 

that it has a front without a distinct notch, carapace regions rise feebly and divided by narrow

445

446

447

448 grooves and chelipeds without tubercles (Maenosono, 2021). Moreover, Edmonson (1962) indicated that the anterolateral border of the specimens was divided into 4 low teeth in addition to the external orbital angle, while $M$. quinquedentatus have 5 distinct anterolateral teeth behind the external orbital angle. Therefore, an examination of this specimen is necessary.

\section{Macromedaeus crassimanus (A. Milne-Edwards, 1867)}

Xantho crassimanus A. Milne-Edwards, 1867: 267; Rathbun, 1906: 847; Edmondson, 1925: 51; Edmondson, 1962: 239, fig. 6c; Buitendijk 1960: 318, figs. 9c-f.

Leptodius crassimanus A. Milne-Edwards, 1873: 226, pl. 11, fig. 4; de Man, 1888: 287; Forest \& Guinot, 1961: 63, fig. 48; de Man, 1895: 522;

Xantho exaratus var. crassimanus Ortmann, 1893: 448.

Xantho (Leptodius) crassimanus Alcock, 1898: 118, 120; Odhner, 1925: 80.

Macromedaeus crassimanus Guinot, 1968: 708, figs. 18, 22; Takeda, 1976: 85; Serène, 1984: 177 (keys), 179, fig. 103, pl. 25b; Dai et al., 1968: 266, fig. 151-2; Dai \& Yang, 1991: 287, fig. 151-2, pl. 36, fig. 6; Naderloo, 2017: 257, figs. 21, 23; Ho et al., 2000: 114 (list); Ng et al., 2001: 25 (list); Ng et al., 2007: 93 (list); Liu 2008: 797 (list); Maenosono, 2021: 5, figs. 1d-e, figs. 4a-g, fig. 8c.

\section{Material examined}

1 male; Nov. 24, 2007; Xiaodonghai, Hainan (MBM282426); 1 male; Jul. 5-7, 2020; Sanya, Hainan; Yunhao Pan, Fei Meng coll. (MBM286998).

Size. CW: 20.29-29.69mm, CL: 13.29-18.46mm. 
Diagnosis. Carapace (Fig. 12A, B) transversely ovate, the breadth is about 1.6 times the

466

467

468

469

470

471

472

473

474

475

476

477

478

479

480

481

482

483

484

485

486

487

488

489

490

length; dorsal rather convex, surface finely granular, with little pits; anterior $2 / 3$ well-defined by broad and shallow grooves. Front (Fig. 5E) narrow, about 1/5 the breadth of Carapace, produced, divided into 2 lobes by a v-shape notch, edge grainy and sinuous, outer lobes wide and prominent make it a 4-lobes look. Dorsal orbital edge with double cracks, eyestalk with granules near the dorsal proximal border of cornea. Anterolateral border armed with 5 teeth except the outer orbital angle; the posterior two low; third and fourth wide and prominent, the last tooth small and acute. Posterolateral border concave, shorter than the anterolatera. Setae present on carapace lateral surface. Antennule transverse; antennal flagellum filling orbital hiatus. Third maxilliped (Fig. 12C) completely covering buccal orifice; merus subquadrate, with granules, anterolateral angle produced; ischium subrectangular, with a groove. Male thoracic (Fig. 12D) sternites smooth; groove between st1-2 and 3 bending, st4 median line deep.

Chelipeds (Fig. 12E, F) unequal; merus with setae on inner edge; carpus with an inner angle tooth, dorsal surface granular; palm dorsal surface with irregular areoles and granules; fingers black brown, the fixed finger color extending to palm irregularly in male; dactylus curving, with 2 longitudinal grooves dorsally, cutting edges armed with 4 triangular teeth; finger tips spoonshaped.

Ambulatory legs (Fig. 12A, 6D) finely granular; anterior edges clothed with setae; carpus without obvious protuberances on anterior edges; dactylus with spiny granules and setae, tip claw-shaped, posterior margin with spiny granules, without subterminal tooth; dactylo-propodal articulation with underdeveloped lock composed of rounded prolongation on propodus distal lateral margin sliding against lower button on dactylus proximal lateral margin; P5 dactylus tip nearly straight, slightly forward pointed.

Abdominal somites (Fig. 12D) 3-5 completely fused in male. G1 (Fig. 7D, H, L) long and slender, slightly curving laterally; distal tip with an acute apical lobe wrapping the subdistal lobe; subdistal part with subterminal spines curve to dorsal, distal 4 of them on the prominent subdistal 
491

492

493

494

495

496

497

498

499

500

501

502

503

504

505

506

507

508

509

510

511

512

513

514

lobe; outer ventral surface of subdistal part with little spine; apical lobe with the ventral brim curling inward, and with 2 fine blunt extensions in the largest specimen.

\section{Type locality. New Caledonia.}

Distribution. Xisha islands, Hainan Island, Taiwan island; Red Sea, Persian Gulf, Pakistan, India, Sri Lanka, Andaman Islands, Sumatra, Java, Christmas Island, Sulawesi Island, Sabalana Islands, Flores Island, Morotai Island, Misool Island, Aru Islands, Tanimbar Islands, Maluku Islands, Timor Island, Palau, Australia, Japan, New Caledonia, Necker Island, Fiji, Hawaiian Islands, Line Islands, Samoa Islands, Tahiti Island.

Remarks. Milne Edwards (1867) described M. crassimanus from New Caledonia and compared it with similar species. M. crassimanus is similar to Leptodius sanguineus (H. Milne Edwards, 1834) and Leptodius exaratus (H. Milne Edwards, 1834) morphologically, but can be identified by its sinuous, four-lobes like front, the chelipeds with fingers spoon-shaped but less hollow and the G1 with short apical lobe (Milne Edwards A., 1873; Buitendijk, 1960). M. crassimanus is also related to M. quinquedentatus, the morphological differences have been discussed under remarks of the latter.

In the present largest specimen, there are 2 fine blunt extensions on the ventral brim of G1 apical lobe. Similar structure was figured by Forest \& Guinot (1961, fig. 48b) and Dai et al. (1986, fig. 151-2, 1991, fig. 151-2), but replaced by smaller and sharper spines.

\section{Macromedaeus demani (Odhner, 1925)}

Xantho subacutus de Man, 1902: 595, pl. 21 fig. 21.

Xantho demani Odhner, 1925: 83 (part); Balss, 1938: 52; Buitendijk 1960: 327, fig. 9i.

Macromedaeus demani Guinot, 1968: 708; Serène, 1984: 177 (keys), pl. 25, fig. c; Ho et al., 2000: 114 (list); Ng et al., 2001: 25 (list); Ng et al. 2007: 93 (list); Liu 2008: 797 (list); Maenosono, 2021: 7, figs. 1f-g, figs. 5a-f, figs. 6a-f, figs. 8d-e. 
Non Xantho demani Odhner, 1925: 83 (part); Ward, 1932: 244.

516

517

$=$ Lachnopodus subacutus (Stimpson, 1858)

Diagnosis. Buitendijk (1960), Serène (1984) and Maenosono (2021). Islands

Distribution. Taiwan Island; Lesser Soenda Islands, Ternate Island, Maluku Islands, Ryukyu

Remarks. Odhner (1925) identified X. demani (synonym of M. demani) from specimens that identified as Lachnopodus bidentatus (A. Milne-Edwards, 1867) by Alcock (1898) from Andaman Islands and Lachnopodus subacutus (Stimpson, 1858) by De Man (1902) from Ternate. However, Forest and Guinot (1961) did not accept the identification of Odhner (1925), and believed $M$. demani was not an available species. Forest and Guinot (1961) also examined part of specimens of Ward (1932) identified as X. demani collected from Capricorn Group, Queensland, and listed these materials in the synonymia of $L$. subacutus. Buitendijk (1960) examined the materials collected from Ternate and Todore, and approved the availability of $X$. demani. Buitendijk (1960) also listed the differences between this species and L. subacutus, attaching with the G1 figure of $X$. demani which had never been figured before. Maenosono (2021) examined specimens of $M$. demani in similar size with the materials of De Man (1902), and supported that the specimens described by De Man (1902) should be M. demani rather than L. subacutus. The suggestion of Forest and Guinot (1961) have been widely accepted, so some authors listed M. demani materials of De Man (1902), Odhner (1925) or Buitendijk (1960) in synonymia of L. subacutus, mainly Forest \& Guinot (1961), Takeda (1976) and Dai \& Yang $(1986,1991)$, what caused confusions (Maenosono, 2021).

536 The most striking differences between M. demani and L. bidentatus or L. subacutus are: chelipeds with finger tips spoon-shaped in M. demani (it sharp in L. bidentatus and L. subacutus); G1 with apical lobe wraping the subdistal lobe in M. demani (it with two sharp apical lobes in $L$. bidentatus and L. subacutus) (Buitendijk, 1960; Maenosono, 2021). 


\section{Molecular data analyses}

541

542

543

Molecular phylogenetic analyses were performed on 16 species within 7 genera (Table 1). BI and ML trees of the combined data produce similar structures. BI posterior probabilities (PP) and ML bootstrap replications (BS) were labeled (Fig. 13).

The present phylogenetic analyses indicated that the genus Microcassiope was located at the base part of the Xanthidae and not associated with the species of Macromedaeus (PP100/BS100), making Xanthinae polyphyletic. Two genera, Macromedaeus and Leptodius were identified as sister taxa (PP100/BS100), in accordance with the morphological conclusion. Etisus was not a monophyly taxon now that Etisus sakaii Takeda \& Miyake, 1968 associated with Macromedaeus and Leptodius (PP80/BS-). G1 of the species was characterized with mushroom-like extensions on the ventral brim of apical lobe and curving spine on the subdistal lobe (see Takeda \& Miyake, 1968, Fig. 3a-c). Similar morphological characteristics are present on Leptodius and Mac 2, both of which had the curving subdistal spines and mushroom-like, tongue-like or sawtooth-like extensions on the ventral brim of G1 apical lobe. In addition, the status of E. anaglyptus H. Milne Edwards, 1834 was slightly different in ML and BI trees.

Five species of genus Macromedaeus formed a monophyly clade with high support values (PP100/BS91). The genetic divergences of COI between M. hainanensis sp. nov. and other four congeneric species were higher than 0.09 (Table 2). These species can be further divided into two clades, Mac 1 (PP100/BS95) and Mac 2 (PP100/BS100), which were well supported. Mac 1 contained the new species M. hainanensis sp. nov., M. orientalis and M. distinguendus. They share similar morphological characteristics, including 4 anterolateral teeth, front with not produced and narrow outer lobes, G1 more curved, the subdistal part with larger short spines on the outer surface, while sparser long spines on the inner surface, and apical lobe of G1 without extensions on ventral brim. Mac 2 contained M. quinquedentatus and M. crassimanus. They shared the following morphological characteristics: 5 anterolateral teeth, front with produced and wider outer lobes, make a 4-lobes look, G1 more direct, the subdistal part with smaller short spines on the outer 
566

567

568

569

570

571

572

573

574

575

576

577

578

579

580

581

582

583

584

585

586

587

588

589

590

surface, while denser long spines on the inner surface, and apical lobe of G1 with obvious or fuzzy extensions on ventral brim.

\section{Discussion}

In the present study, a new species, M. hainanensis sp. nov., is described. M. hainanensis sp. nov. was identified from other Macromedaeus species by morphological characteristics and phylogenetic analyses. Two newly recorded species of Chinese waters, M. orientalis and $M$. quinquedentatus are reported. The controversial species $M$. orientalis was classified in Macromedaeus based on morphological and phylogenetic evidence. Geographical distributions of these species were summarized. A key of Macromedaeus species was provided. Consideration of the obvious variation on the carapace, the morphology of G1, front and P5 should be better diagnostic characteristics for Macromedaeus.

The phylogenetic analyses confirmed the monophyly of Macromedaeus based on species involved. Macromedaeus can be divided into two clades, Mac1 and Mac2. Species of the same clade share similar characteristics that are consistent with the morphological results. However, the Etisus and Xanthinae were not monophyletic in the present study. Microcassiope located near the base of Xanthidae in our trees and similar topological structure shown in the phylogenetic research of Thoma et al. (2014). E. sakaii is associated with the clade of Macromedaeus and Leptodius. It shares similar G1 form with part of species in this clade, that with mushroom-like or tongue-like extensions. Further study will make sure is this characteristic has broader phylogenetic significance, now that similar structure also known in other Xanthidae species such as Etisus electra (Herbst, 1801), Etisus frontalis (Dana, 1852) Etisus demani Odhner, 1925, and Liocarpilodes armiger (Nobili, 1906).

Key to species of Macromedaeus Ward, 1942 (adapted from Serène (1984) and Maenosono (2021))

1. Anterolateral border with about ten short, irregular teeth with obtuse apices. The surface of the 
591 carapace and chelipeds is irregularly hollowed giving it a reticulated appearance; P5 dactylus with 592 spiny granules, larger in terminal; G1 see Serène, 1984, fig.101 M. nudipes

593 - Anterolateral border with 4-5 teeth or lobes 2

594 2. Anterolateral border with 5 teeth, front sinuous, with produced and wide outer lobes, make a 4595 teeth look

3. Carapace regions with areolae sharper, separated by large deep grooves; chelipeds palm armed with prominent tubercles on superoexternal margin; G1 with 5-16 sawtooth-like extensions on ventral brim M. quinquedentatus

600

601

602

- Carapace regions slightly projecting, separated by broad, shallow furrows; chelipeds only with rugose on superoexternal margin, external surface smoother; G1 with the ventral brim curling inward with very fine blunt extensions M. crassimanus

4. Anterolateral border with 4 feeble lobes, first two are sometimes not easily distinguished one from the other; surface of carapace and chelipeds have small hollows, giving them a slightly rugose aspect; P5 dactylus with granules, larger in terminal; G1 see Buitendijk ,1960 fig.9j....... demani - Anterolateral border with 4 distinct teeth; surface of carapace and chelipeds with granules .......5 5. Carapace regions noticeably projecting, separated by deeper and more acute furrows; anterolateral teeth with noticeably projecting apices forming an acute angle; surface of carapace and chelipeds is irregularly granular. the granules are much larger and more acute on the frontal margin, tantero-lateral teeth and neighboring regions, superoexternal parts of the carpus and propodus of the chelipeds and the anterior margins of the ambulatory legs; rows of transverse, irregular, acute granules occur here and there on the carapace regions. G1 see Serène, 1984, fig. 102 M. voeltzkowi 
615 6. Front produced, not double-rimmed; anterolateral teeth broader, apices slightly projecting, 616 forming an obtuse angle; ambulatory legs carpus with 3 crests, dactylus without distinct 617 subterminal tooth M. distinguendus

618 - Front not so produced, double-rimmed; anterolateral teeth narrower, apices projecting forming 619 an acute angle; ambulatory legs carpus without obvious crests, a sharp and strong subterminal 620 tooth on dactylus of last three legs .7

621 7. P5 slender, especially the obvious prolonged propodus and dactylus; dactylus tip prolonged, 622 curved backward; the color of fixed finger extending to palm irregularly in male chelipeds; G1 623 more stout, distal tip with a apical lobe slightly upturned, the apical lobe dorsal rim more prominent 624 than the ventral rim M. orientalis

\section{Conclusions} helpful to clarify the status of other Xanthidae crabs.

\section{Acknowledgements}

- P5 stout, dactylus tip stout, nearly straight, slightly pointed forward; the colour of fixed finger nearly not extend to palm in chelipeds; G1 more slender, apical lobe not upturned, the ventral rim more prominent than the dorsal rim M. hainanensis sp. nov.

hainanensis sp. nov. is most similar to M. distinguendus and M. orientalis, but can be distinguished by morphological and molecular evidence. $M$. orientalis and $M$. quinquedentatus were reported from Chinese waters for the first time, and the six Macromedaeus species present recorded from Chinese waters were reviewed using integrative taxonomy methods. M. orientalis should be transferred to Macromedaeus instead of Microcassiope. The present analysis supports the monophyletic of Macromedaeus, which can be further divided into two clades well supported, but Etisus and Xanthinae are not monophyletic. Further phylogenetic studies involving more taxa are 
Xian, Julong Zhang, Shuqian Zhang and other scientists and participants for their help in collecting

641 materials. We are also thankful to Xu Zhang for providing photographs of living crabs used in this 642 paper.

\section{References}

Alcock A. (1898) Materials for a carcinological fauna of India. No. 3. The Brachyura Cyclometopa. Part I. The family Xanthidae. Journal of the Asiatic Society of Bengal 67(2): 67-33.

Alcock A. \& Anderson A.R.S. (1899) Crustacea, Part VII. Illustrations of the zoology of the Royal Indian Marine Surveying Steamer "Investigator" Calcutta: Trustees of the Indian Museum., Plates XXXVI-LV.

Apakupakul K., Siddall M. E., Burreson E. M. (1999) Higher level relationships of leeches (Annelida: Clitellata: Euhirudinea) based on morphology and gene sequences. Molecular Phylogenetics and Evolution 12: 350-59. https://doi.org/10.1006/mpev.1999.0639

Apel M. (2001) Taxonomie und Zoogeographie der Brachyura, Paguidea und Porcellanidae (Crustacea: Decapoda) des Persisch-Arabischen Golfes. Biologie und Informatik. Advisor: Prof. Dr. K. D. Entian. Degree: Ph. D. Frankfurt am Main: Johann Wolfgang GoetheUniversität. 260 pp.

Balss H. (1922) Diagnosen neuer japanischer Decapoden. Zoologischer Anzeiger 54(1/2): 1-6.

Balss H. (1924) Expeditionen S. M. Schiff "Pola" in das Rote Meer. Nördliche und südliche Hälfte. 1895/96-1897/98 Zoologische Ergebnisse XXXIV Decapoden des Roten Meeres III Die Parthenopiden, Cyclo- und Catometopen. Denkschriften der Kaiserlichen Akademie der Wissenschaften. Mathematisch-Naturwissenschaftliche Classe 99(6): 1-18.

Balss H. (1938) Ueber einige Xanthidae (Crustaea Dekapoda) von Singapore und Umgebung. 
663

664

665

666

667

668

669

670

671

672

673

674

675

676

677

678

679

680

681

682

683

684

685

Bulletin of the Raffles Museum 14: 48-63.

Barnard K. H. (1950) Descriptive catalogue of South African decapod Crustacea (crabs and shrimps). Annals of the South African Museum 38: 1-837.

Buhay J. E., Moni G., Mann N., Crandall K. A. (2007) Molecular taxonomy in the dark: evolutionary history, phylogeography, and diversity of cave crayfish in the subgenus Aviticambarus, genus Cambarus. Molecular Phylogenetics and Evolution 42: 435-438. https://doi.org/10.1016/j.ympev.2006.07.014

Buitendijk A. M. (1960) Biological results of the Snellius Expedition XXI. Brachyura of the families Atelecyclidae and Xanthidae (Part I). Temminckia 5: 252-338.

Chhapgar B.F. (1957) On the marine crabs (Decapoda: Brachyura) of Bombay State Part II. Journal of the Bombay Natural History Society 54(3): 503-549.

Dai A. Y., Yang S. L., Song Y. Z., Chen G. X. (1986) Crabs of the China Seas. China Ocean Press, Beijing, $17+642$ pp., figs. 1-295, pls. 1-74.

Dai A. Y. \& Yang S. L. (1991) Crabs of the China Seas. China Ocean Press, Beijing and SpringerVerlag, Berlin, Heidelberg, New York, Tokyo, English edition, i-iv, 1-608, figs. 1-295, pls. 1-74. (Translation from Chinese original 1986.)

Dana J. D. (1852) Crustacea. Part I. United States Exploring Expedition. During the years 1838, 1839, 1840, 1841, 1842. Under the command of Charles Wilkes, U.S.N. Vol. 13. Sherman C, Philadelphia. 685p. https://doi.org/10.5962/bhl.title.69333

Edmondson C. H. (1925) Marine zoology of tropical central Pacific. Crustacea. Bulletin of the Bernice P. Bishop Museum 27: 3-62.

Edmondson C. H. (1962) Xanthidae of Hawaii. Occasional Papers of Bernice P. Bishop Museum 22(13): 215-309. 
686 Forest J. and Guinot D. (1961) Crustacés Décapodes Brachyoures de Tahiti et des Tuamotu. In: 687 Expédition Français sur les Récifs Coralliens de la Nouvelle-Calédonie. Paris: A. Lahure. 1$688 \quad 195$.

689

690

691

692

693

694

695

696

697

698

699

700

701

702

703

704

705

706

707

708

709

Galil B. \& Vannini M. (1990) Research on the coast of Somalia. Xanthidae, Trapeziidae, Carpiliidae, Menippidae (Crustacea Brachyura). Tropical Zoology 3: 21-56. https://doi.org/10.1080/03946975.1990.10539447

Ghotbeddin N. \& Naderloo R. (2014) Confirming of the occurrence of three intertidal xanthid crabs (crustacea: decapoda: brachyura: xanthidae) in the gulf of oman. Marine Biodiversity Records 7: 1-5. https://doi.org/10.1017/S1755267214000712

Gordon I. (1931) Brachyura from the coasts of China. Journal of the Linnean Society of London. Zoology 37(254): 525-558. https://doi.org/10.1111/j.1096-3642.1931.tb02365.x

Guinot D. (1967) Recherches préliminaires sur les groupements naturels chez les Crustacés Décapodes Brachyoures. II. Les anciens genres Micropanope Stimpson et Medaeus Dana. Bulletin du Muséum national d'Histoire naturelle, Paris, 2e série 39(2): 345-374.

Guinot D. (1968) Recherches préliminaires sur les groupements naturels chez les Crustacés Décapodes Brachyoures. IV. Observations sur quelques genres de Xanthidae. Bulletin du Muséum national d'Histoire naturelle, Paris, 2e série 39(4): 695-727.

Guinot D. (1971) Recherches préliminaries sur les groupements naturels chez les Crustacés Décapodes Brachyoures VIII. Synthèse et bibliographie. Bulletin du Muséum national d'Histoire naturelle, Paris, 2e série 42(5): 1063-1090. https://www.researchgate.net/publication/292575698_Recherches_preliminaires_sur_les_gr oupements_naturels_chez_les_Crustaces_Decapodes_Brachyoures_VIII_Synthese_et_bibli ographie

Haan W. de (1833-1850) Crustacea. In: Siebold P F von ed., Fauna Japonica sive Descriptio 
710

711

712

713

714

715

716

717

718

719

720

721

722

723

724

725

726

727

728

729

730

731

732

733

Animalium, Quae in Itinere per Japoniam, Jussu et Auspiciis Superiorum, qui Summum in India Batava Imperium Tenent, Suscepto, Annis 1823-1830 Collegit, Noitis, Observationibus et Adumbrationibus Illustravit. Lugduni Batavorum, Leiden. 1-17, 1-31, 1-243, pls. 1-55, AQ, 2. https://doi.org/10.5962/bhl.title.124951

Heller C. (1861) Beiträge zur Crustaceen-Fauna des Rothen Meeres. I. Theil. Sitzungsberichte der Mathematisch-Naturwissenschaftlichen Klasse der Kaiserlichen Akademie der Wissenschaften, Wien 43: 297-374. https://doi.org/10.5962/bhl.title.120013

Henderson J. R. (1893) A contribution to Indian carcinology. Transactions of the Linnean Society of London, series 2, Zoology 5(10): 325-458, pls. 36-40. https://doi.org/10.1111/j.10963642.1893.tb00653.x

Herbst J. F. W. (1801) Versuch einer Naturgeschichte der Krabben und Krebse nebst einer systematischen Beschreibung ihrer verschiedenen Arten, 3(2): 1-46, pls. 51-54.

Ho P. H., Yu H. P., Ng P. K. L. (2000). New records of eriphiidae, pilumnidae and xanthidae (crustacea: decapoda: brachyura) from taiwan. The Raffles Bulletin of Zoology, 48(1): 111122.

Huelsenbeck J. P. \& Ronquist F. (2001) MRBAYES: Bayesian inference of phylogeny. Bioinformatics 17: 754-755. https://doi.org/10.1093/bioinformatics/17.8.754

Jana T., Lam-Tung N., Arndt V. H., Quang M. B. (2016). W-iq-tree: a fast online phylogenetic tool for maximum likelihood analysis. Nucleic Acids Research(W1), W232-W235. https://doi.org/10.1093/nar/gkw256

Kim H. S. (1973) A Catalogue of Anomura and Brachyura from Korea. In: Illustrated Encyclopedia of Fauna and Flora of Korea, Samhwa Publishing Company, Seoul, 14: 1-694, figs. 1-265, pls. 1-112, tables. 1-2, 1 map.

Klunzinger C. B. (1913) Die Rundkrabben (Cyclometopa) des Roten Meeres. Abhandlungen der 
734

735

736

737

738

739

740

741

742

743

744

745

746

747

748

749

750

751

752

753

754

755

756

757

758

kaiserlich Leop. -Carol. Deutschen Akademie der Naturforscher Halle 2: 97-402, figs. 1-4, pls. 5-11.

Krauss F. (1843) Die Südafrikanischen Crustaceen. Eine Zusammenstellung aller bekannten Malacostraca, Bemerkungen über deren Lebensweise und geographische Verbreitung, nebst Beschrwibung und Abbildung mehrer neuen Arten. Schweizerbartsche, Stuttgart, 68 pp., 4 pls. https://doi.org/10.5962/bhl.title.4825

Lai J C Y, Mendoza J C E, Guinot D, Clark P F, Ng P K L. 2011. Xanthidae Macleay, 1838 (Decapoda: Brachyura: Xanthoidea) systematics: a multi-gene approach with support from adult and zoeal morphology. Zoologischer Anzeiger, 250(4): 407-448, https://doi.org/10.1016/j.jcz.2011.07.002.

Laurie R. D. (1906) Report on the Brachyura collected by Professor Herdman, at Ceylon, in 1902. In: Herdman, W.A. (ed.) Report to the Government of Ceylon on the Pearl Oyster Fisheries of the Gulf of Manaar with Supplementary Reports Upon the Marine Biology of Ceylon by Other Naturalists, Part 5, Suppl. Rep. 40. pp. 349-432, pls. 1-2.

Lee K. H., Ko H. S. (2008) First Records of Three Crabs (Crustacea: Decapoda) from Korea. Animal Systematics, Evolution and Diversity 24(1): 17-24. https://doi.org/10.5635/KJSZ.2008.24.1.017

Lee S K. (2012) Systematic study on the Korean pilumnoid and xanthoids (Crustacea: Decapoda: Brachyura) based on morphology and molecular data. Laboratory of Systemtics and Molecular evolution, School of Biological Sciences, The Graduate School, Seoul National Universit, Seoul. 343 pp.

Lenz H. (1905). Ostafrikanische Dekapoden und Stomatopoden gesammelt von Herrn Prof. Dr. A. Voeltzkow. In: Wissenschaftliche Ergebnisse der Reisen in Madagaskar und Ostafrika in den Jahren 1889-95 von Dr. A. Voeltzkow. Band III. Abhandlungen herausgegeben von der Senckenbergischen Naturforschenden Gesellschaft. 27(4): 339-392, pls. 47-48.

Peer) reviewing PDF | (2021:09:65290:2:0:NEW 10 Dec 2021) 
759

760

761

762

763

764

765

766

767

768

769

770

771

772

773

774

775

776

777

778

779

780

781

782

Liu J. Y. (ed.). (2008). Checklist of marine biota of China seas. China Science Press. 1267 pp.

Man J. G. de (1887) Report on the podophthalmous Crustacea of the Mergui Archipelago, collected for the Trustees of the Indian Museum, Calcutta, by Dr. John Anderson, F.R.S., Superintendent of the Museum. Part I. Journal of the Linnean Society of London. Zoology 22: 1-64. https://doi.org/10.1111/j.1096-3642.1887.tb00027.x

Man J.G. de (1895) Bericht über die von Herrn Schiffscapitän Storm zu Atjeh, an den westlichen Küsten von Malakka, Borneo und Celebes sowie in der Java-See gesammelten Decapoden und Stomatopoden. Zoologische Jahrbücher. Abteilung für Systematik, Geographie und

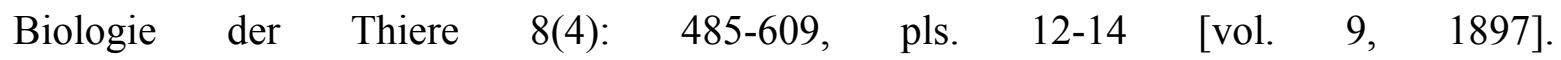
https://doi.org/10.5962/bhl.title.16084

Man J.G. de (1902) Die von Herrn Professor Kükenthal im Indischen Archipel gesammelten Dekapoden und Stomatopoden. Abhandlungen der Senckenbergischen Naturforschenden Gesellschaft 25: 467-929, pls. XIX-XXVII. https://doi.org/10.5962/bhl.title.10409

Man J.G. de (1888) Bericht über die von Herrn. Dr. J. Brock im indischen Archipel gesammelten Decapoden und Stomatopoden. Archiv für Naturgeschichte, Berlin, 53(1): 215-288, pls 7-10. https://doi.org/10.5962/bhl.part.4747

Medlin L., Elwood H. J., Stickel S., Sogin M. L. (1988) The characterization of enzymatically amplified eukaryotic 16slike rRNA-coding regions. Gene 71: 491-499. https://doi.org/10.1016/0378-1119(88)90066-2

Mendoza J. C. E., Lasley Jr. R. M., Ng P. K. L. (2014). New rock crab records (Crustacea: Brachyura: Xanthidae) from christmas and cocos (keeling) islands, eastern indian ocean. The Raffles Bulletin of Zoology, Supplement No. 30, 274-300.

Meyer C. P. (2015). Molecular systematics of cowries (gastropoda: cypraeidae) and diversification patterns in the tropics. Biological Journal of the Linnean Society, 79(3): 401-459. 
784

Milne-Edwards A. (1867) Descriptions de quelques espéces nouvelles de Crustacés Brachyures. Annales de la Société entomologique de France, 4e série 7: 263-288.

Milne Edwards A. (1873) Recherches sur la faune carcinologique de la Nouvelle-Calédonie. Part II. Groupe des Cyclométopes Portuniens. Nouvelles archives du Muséum national d'Histoire naturelle, Paris, 9: 155-332, pls 4-18. https://doi.org/10.5962/bhl.title.10410

Milne Edwards H. (1834-1840) Histoire naturelle des Crustacés, comprenant l' anatomie, la physiologie et la classification de ces animaux. Vol. 1-3. Paris: Librairie Encyclopédique de Roret. (1) 468 , (2) 532 , (3)638p, Atlas. $1-32, \quad$ pls. I-XLII, https://doi.org/10.5962/bhl.title.16170.

Naderloo R. (2017) Atlas of crabs of the Persian Gulf. Springer eBooks, 444 pp. https://doi.org/10.1007/978-3-319-49374-9

Ng P. K. L., Guinot D., Davie P. J. F. (2008) Systema Brachyurorum: part I. an annotated checklist of extant brachyuran crabs of the world. The Raffles Bulletin of Zoology, 17: 1-286. https://kcnhm.nus.edu.sg/rbz/supplement-no-17/. Accessed on 2019-08-20

Ng P. K. L., Shih H. T., Ho P. H., Wang C. H. (2017) An updated annotated checklist of brachyuran crabs from Taiwan (Crustacea: Decapoda). Journal of The National Taiwan Museum, 70(3 \& 4): 1-185. https://doi.org/10.6532/JNTM.201712_70(3;4).01

Ng P. K. L., Wang C. H., Ho P. H., Shih H. T. (2001) An annotated checklist of brachyuran crabs from Taiwan (Crustacea: Decapoda). National Taiwan Museum Special Publication Series, Number 11: 1-86, 8 pls.

Nobili G. (1906) Faune carcinologique de la Mer Rouge. Décapodes et stomatopodes. Annales des Sciences Naturelles, 9e série 4: 1-347. https://doi.org/10.5962/bhl.title.10635

Nobili G. (1906) Diagnoses préliminaires de 34 espèces et variétés nouvelles, et de 2 genres 
807

808

809

810

811

812

813

814

815

816

817

818

819

820

821

822

823

824

825

826

827

828

829

830

nouveaux de Décapodes de la Mer Rouge. Bulletin du Muséum d'Histoire Naturelle. 6: 393411.

Odhner T. (1925) Monographierte Gattungen der Krab benfamilie Xanthidae. 1. Göteborgs Kungliga Vetens kaps-och Vitterhets-Samhälles Handlingar, (4), 29: 1-92, pls. 1-5. https://decapoda.nhm.org/references/referenceinfo.html?refid=10701. Accessed on 2019-1012.

Ortmann A. E. (1893) Die Decapoden-Krebse des Strassburger Museums, mit besonderer Berücksichtigung der von Herrn Dr. Döderlein bei Japan und bei den Liu-Kiu-Inseln gesammelten und zur Zeit im Strassburger Museum aufbewahrten Formen. VII. Theil. Abtheilung: Brachyura (Brachyura genuina Boas) II. Unterabtheilung: Cancroidea, 2. Section: Cancrinea, 1. Gruppe: Cyclometopa. Zoologische Jahrbücher. Abteilung für Systematik, Geographie und Biologie der Thiere 7(3): 411-495, pl. 17. https://doi.org/10.5962/bhl.part.24064

Palumbi S. R. (1996) Nucleic acids II: the polymerase chain reaction. In: Molecular Systematics (eds Hillis DM, Moritz C, Mable BK), Sinauer \& Associates Inc., Sunderland, Massachusetts, pp. $205-247$.

Posada D. (2008) jModelTest: Phylogenetic model averaging. Molecular Biology and Evolution 25: 1253-1256. https://doi.org/10.1093/molbev/msn083

Rathbun M. J. (1906) The Brachyura and Macrura of the Hawaiian islands. Bulletin of the Bureau of Fisheries 23(3): 827-930, pls. 1-24.

Rathbun M. J. (1931) New and rare Chinese crabs. Lingnan Science Journal 8: 75-104, pls. 5-15.

Sakai T. (1939) Studies on the Crabs of Japan IV. Brachygnatha, Brachyrhyncha. Vol. 3. Tokyo: Yokendo Co., Ltd.. pp. 365-741.

Sakai T. (1976) Crabs of Japan and the Adjacent Seas. Tokyo: Kodansha Ltd.. 773 pp., 251 pls. 
831 Sendler A. (1923) Die Dekapoden und Stomatopoden der Hanseatischen Südsee-Expedition. 832 Abhandlungen der Senckenbergischen naturforschenden Gesellschaft, Frankfurt a. M., 38: $833 \quad 21-47$, figs. 1-3, pls. 5-6.

834

835

836

837

838

839

840

841

842

843

844

845

846

847

848

849

850

851

852

853

854

855

Serène R. (1984) Crustacés Décapodes Brachyoures de l'Océan Indien occidental et de la Mer Rouge. Xanthoi dea: Xanthidae et Trapeziidae. Addendum Carpiliidae et Menippidae by A. Crosnier. $\quad$ Faune $\quad$ Tropicale, 24: 1-349, pls. 1-48. https://decapoda.nhm.org/references/referenceinfo.html?refid=11789. Accessed on 2019-0815.

Shen C.J. (1932) The Brachyuran Crustacea of North China. Zoologia Sinica, Peiping, (A) 9(1): ix, 1-320, figs. 1-171, pls. 1-10, 1 map.

Stebbing T. R. R. (1918) Some Crustacea of the Natal. IV. Annals of Durban Museum, 2(2): 4775 , pls. $8-12$.

Stimpson W. (1858) Prodromus descriptionis animalium evertebratorum, quae in Expeditione ad Oceanum Pacificum Septentrionalem, a Republica Federata missa, Cadwaladaro Ringgold et Johanne Rodgers Ducibus, observavit et descripsit W. Stimpson. Pars IV. Crustacea Cancroidea et Coryoidea. Proceedings of the Academy of Natural Sciences, Philadelphia. 10: 31-40. https://doi.org/10.5962/bhl.title.51447

Stimpson W. (1858) Prodromus descriptionis animalium evertebratorum, quae in Expeditione ad Oceanum Pacificum Septentrionalem, a Republica Federata missa, Cadwaladaro Ringgold et Johanne Rodgers ducibus, observavit et descripsit. Pars IV. Crustacea Cancroidea et Corystoidea. Proceedings of the Academy of Natural Sciences of Philadelphia, 1858 (March), 10: 31-40. https://doi.org/10.5962/bhl.title.51447

Svenson G. J., Whiting M. F. (2004) Phylogeny of Mantodea based on molecular data: evolution of a charismatic predator. Systematic Entomology 29: 359-370. https://doi.org/10.1111/j.0307-6970.2004.00240.x 
856

857

858

859

860

861

862

863

864

865

866

867

868

869

870

871

872

873

874

875

876

877

878

879

Maenosono T. (2021). Report on five xanthid crabs of the genus Macromedaeus Ward, 1942 (Crustacea: Decapoda: Brachyura) collected from southern Japan, including three new records from the Japanese waters. Fauna Ryukyuana, 59: 1-15.

Tamura K., Stecher G., Peterson D., Filipski A., Kumar S. (2013) MEGA6: Molecular Evolutionary Genetics Analysis version 6.0. Molecular Biology and Evolution, 30: 27252729. https://doi.org/10.1093/molbev/mst197

Takeda M. (1976) Studies on the Crustacea Brachyura of the Palau Islands, III. Xanthidae. Researches on Crustacea 7: 69-99. https://doi.org/10.18353/rcustacea.7.0 69

Takeda M. (1977) Crabs from shallow waters off Mage-jima Island, Southwest Japan. Bulletin of the National Science Museum, Tokyo, series A (Zoology) A (Zoology). 2: 74-89.

Takeda M., Miyake S. (1968) A new xanthid crab of the genus Etisus from the Palau Islands. OHMU Occasional Papers of Zoological Laboratory, Faculty of Agriculture, Kyushu University, Fukuoka, Japan 1(11): 201-210.

Takeda M., Miyake S. (1969) On two species of the family Xanthidae (Crustacea, Brachyura) from southern Japan. Zoological Laboratory, Faculty of Agriculture, Kyushu University 2: 196206.

Thoma B. P., Danièle G., Felder D. L. (2014) Evolutionary relationships among american mud crabs (crustacea: decapoda: brachyura: xanthoidea) inferred from nuclear and mitochondrial markers, with comments on adult morphology. Zoological Journal of the Linnean Society (1): 86-109.

Vaidya G., Lohman D. J., Meier, R. (2011) Sequencematrix: concatenation software for the fast assembly of multi-gene datasets with character set and codon information. Cladistics, accepted. http://dx.doi.org/10.1111/j.1096-0031.2010.00329.x

Ward M. (1932) The true crabs of the Capricorn Group, Queensland (Class Crustacea, Order 
Ward M. (1935) Notes on a collection of crabs from Christmas Island, Indian Ocean. Bulletin of

883
Ward M. (1942) Notes on the Crustacea of the Desjardins Museum, Mauritius Institute, with descriptions of new genera and species. The Mauritius Institute Bulletin 2(2): 49-108, pls. 56.

Yamaguchi T. M., Takeda M., Tokudome K. (1976) A list oi crabs collected in the vicinity of the Aitsu Marine Biological Station and a preliminary report on the cheliped asymmetry of the crabs. Calanus (Bulletin Aitsu M. B. S. Kumamoto University) (5): 31-46. 


\section{Figure 1}

Holotype of Macromedaeus hainanensis sp. nov., male, $6.54 \times 4.34 \mathrm{~mm}$ (MBM286988)

(A) overall, dorsal view. (B) carapace, dorsal view. (C) third maxillipeds and pterygostomian region, anterior view. (D) thoracic sternites and abdomen. (E) right cheliped, outer view. (F) left cheliped, outer view. Scale bars $=2 \mathrm{~mm}$. 


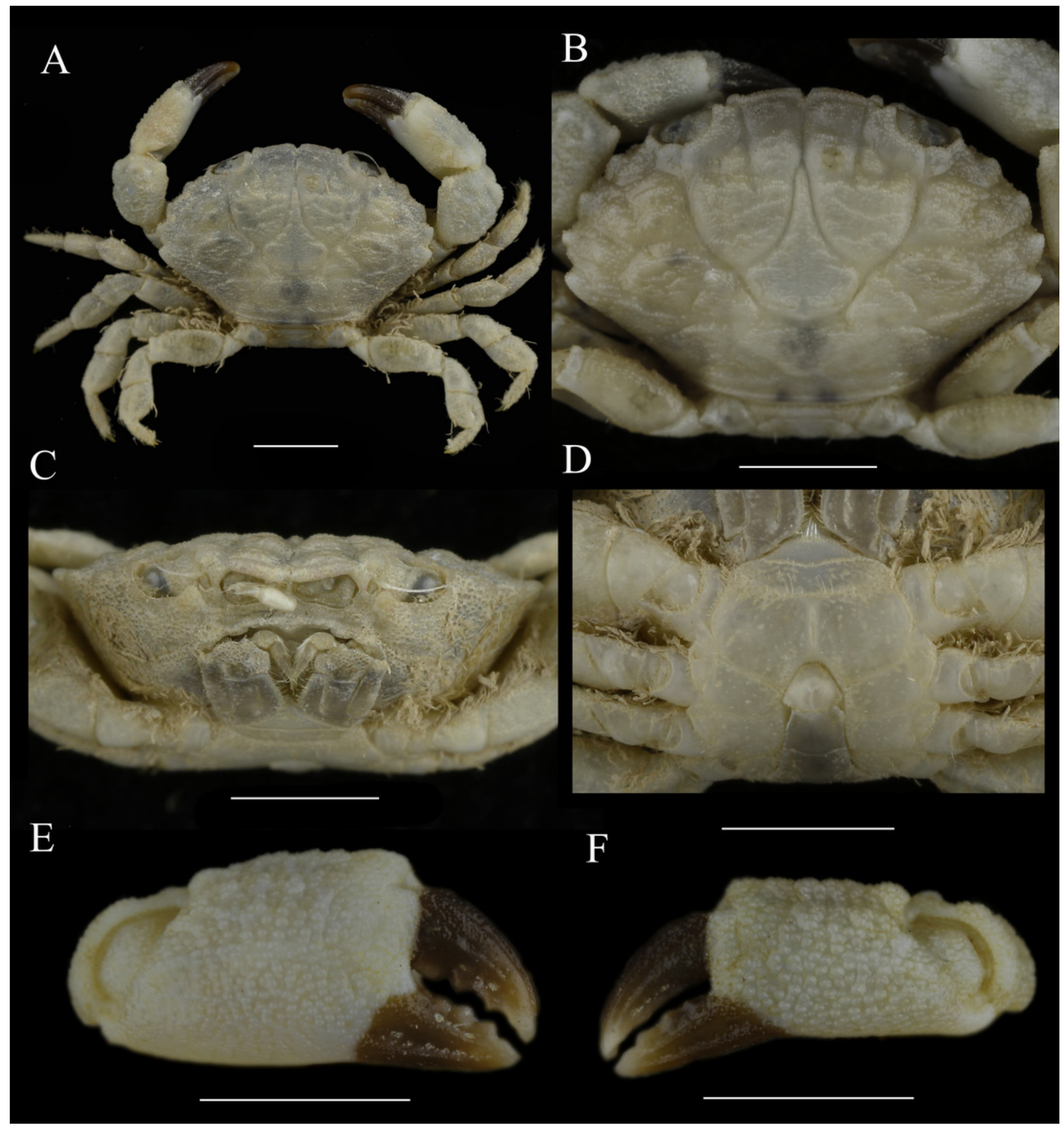


Figure 2

Holotype of Macromedaeus hainanensis sp. nov., male, $6.54 \times 4.34 \mathrm{~mm}$ (MBM286988)

(A) carapace, dorsal view. (B) third maxillipeds, external view. (C) front, dorsal view. (D) abdomen. (E) P5, dorsal view. (I) G1, left, internal view. (F) same, distal portion, internal view.

(G) same, external view. $(H) G 2$, right, external view. Scale bars: $(A)=2 m m$. $(B-E)=1 \mathrm{~mm}$. (F$H)=0.1 \mathrm{~mm} .(\mathrm{I})=0.5 \mathrm{~mm}$. 

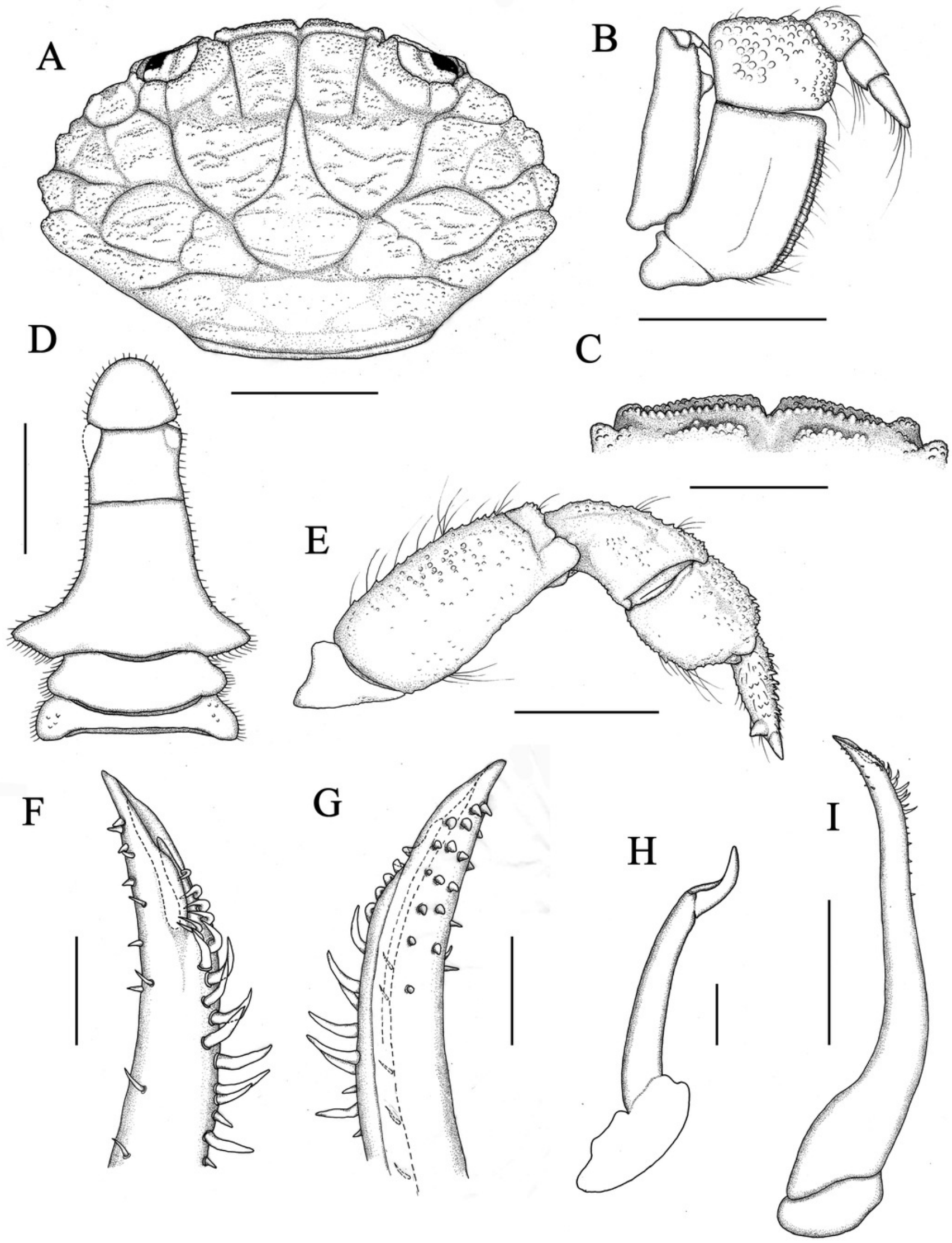


\section{Figure 3}

Paratype of Macromedaeus hainanensis sp. nov., female, $14.69 \times 9.21 \mathrm{~mm}$ (MBM160965)

(A) overall, dorsal view. (B) carapace, dorsal view. (C) third maxillipeds and pterygostomian region, anterior view. (D) thoracic sternites and abdomen. (E) right cheliped, outer view. (F) left cheliped, outer view. Scale bars $=5 \mathrm{~mm}$. 


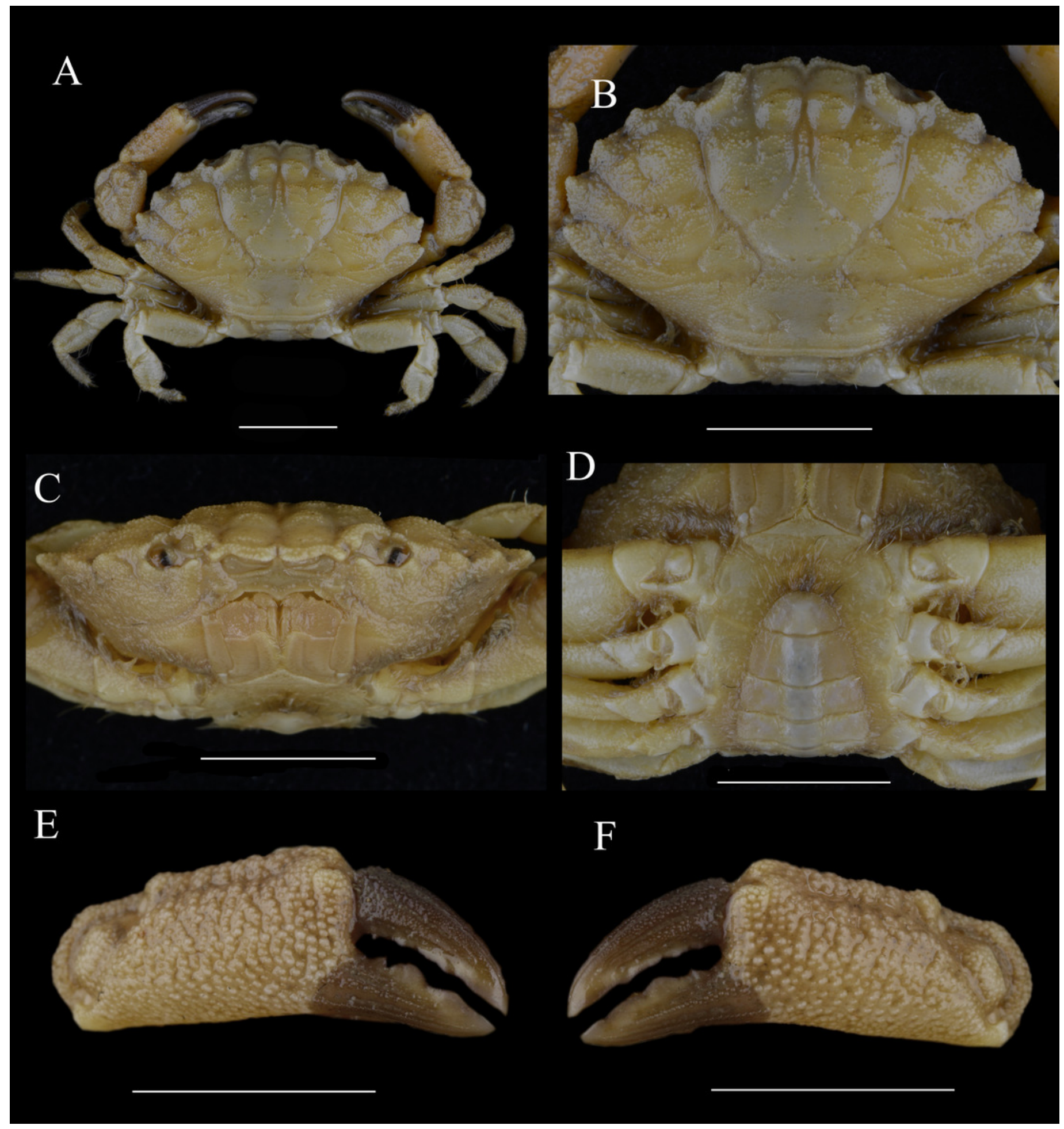


Figure 4

Macromedaeus orientalis (Takeda \& Miyake, 1969), male, 6.85×4.43mm (MBM286994)

(A) overall, dorsal view. (B) carapace, dorsal view. (C) third maxillipeds and pterygostomian region, anterior view. (D) thoracic sternites and abdomen. (E) right cheliped, outer view. (F) left cheliped, outer view. Scale bars $=2 \mathrm{~mm}$. 


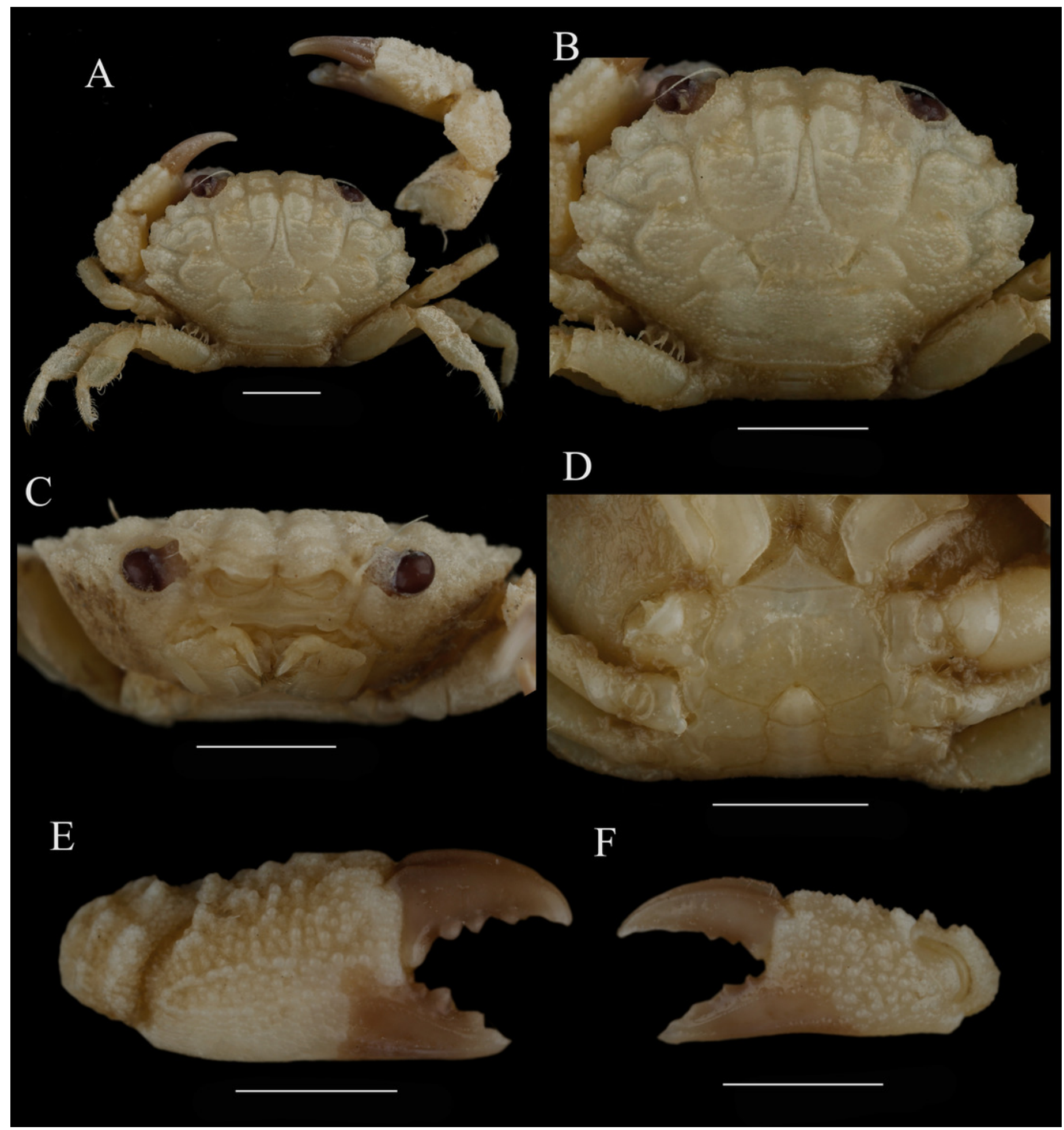


Figure 5

Front of Macromedaeus species, dorsal view.

(A) M. orientalis (Takeda \& Miyake, 1969), male, 6.85×4.43mm (MBM286994). (B) M.

distinguendus (De Haan, 1835), male, 27.76×18.21mm (135CC03764). (C) M. distinguendus

(De Haan, 1835), male, $28.9 \times 18.58 \mathrm{~mm}$ (MBM286999). (D) M. quinquedentatus (Krauss, 1843), male, $24.77 \times 15.60 \mathrm{~mm}$ (MBM286997). (E) M. crassimanus (A. Milne-Edwards, 1867), male, $29.69 \times 18.46 \mathrm{~mm}(M B M 282426)$. Scale bars: $(A)=1 \mathrm{~mm}$. $(B-E)=2 \mathrm{~mm}$. 
A

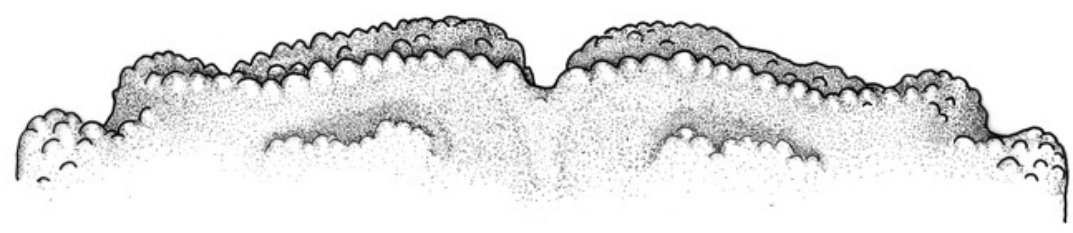

B

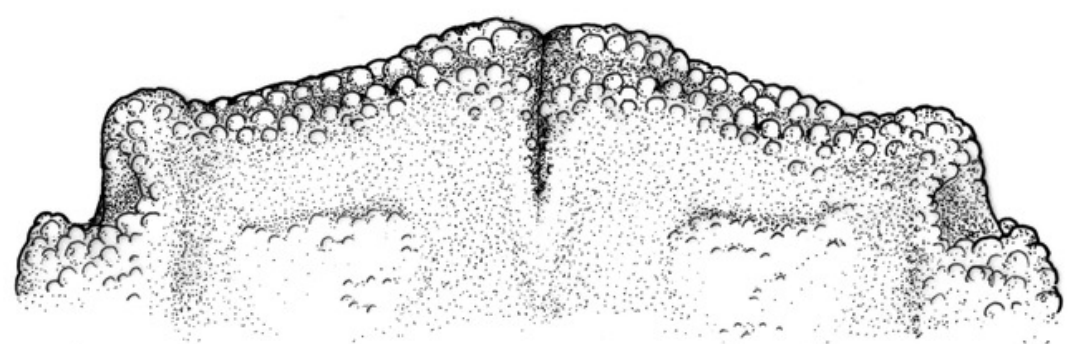

C

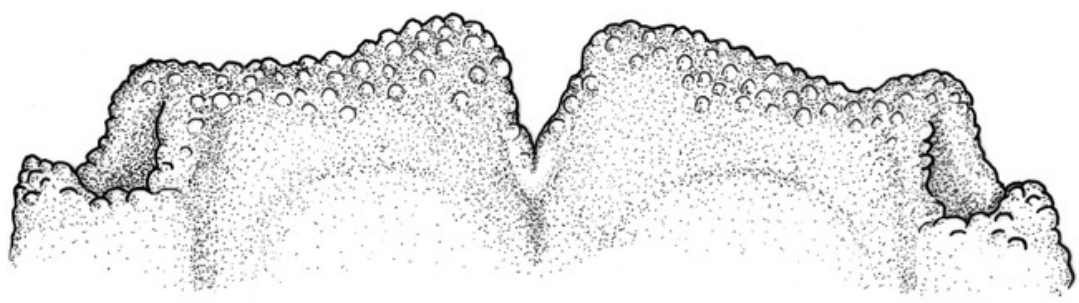

D

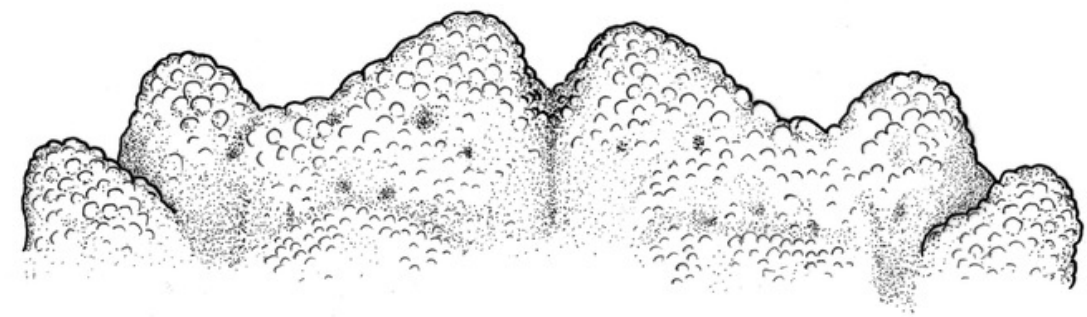

E

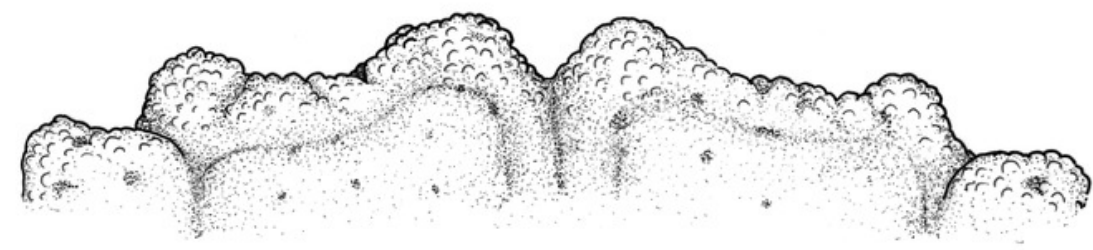


Figure 6

P5 of Macromedaeus species, dorsal view.

(A) M. orientalis (Takeda \& Miyake, 1969), male, $6.85 \times 4.43 \mathrm{~mm}$ (MBM286994). (B) M.

distinguendus (De Haan, 1835), male, 27.76×18.21mm (135CC03764). (C) M.

quinquedentatus (Krauss, 1843), male, $24.77 \times 15.60 \mathrm{~mm}$ (MBM286997). (D) M. crassimanus

(A. Milne-Edwards, 1867), male, $29.69 \times 18.46 \mathrm{~mm}$ (MBM282426). Scale bars: $(A)=1 \mathrm{~mm}$. (B-

D) $=2 \mathrm{~mm}$. 


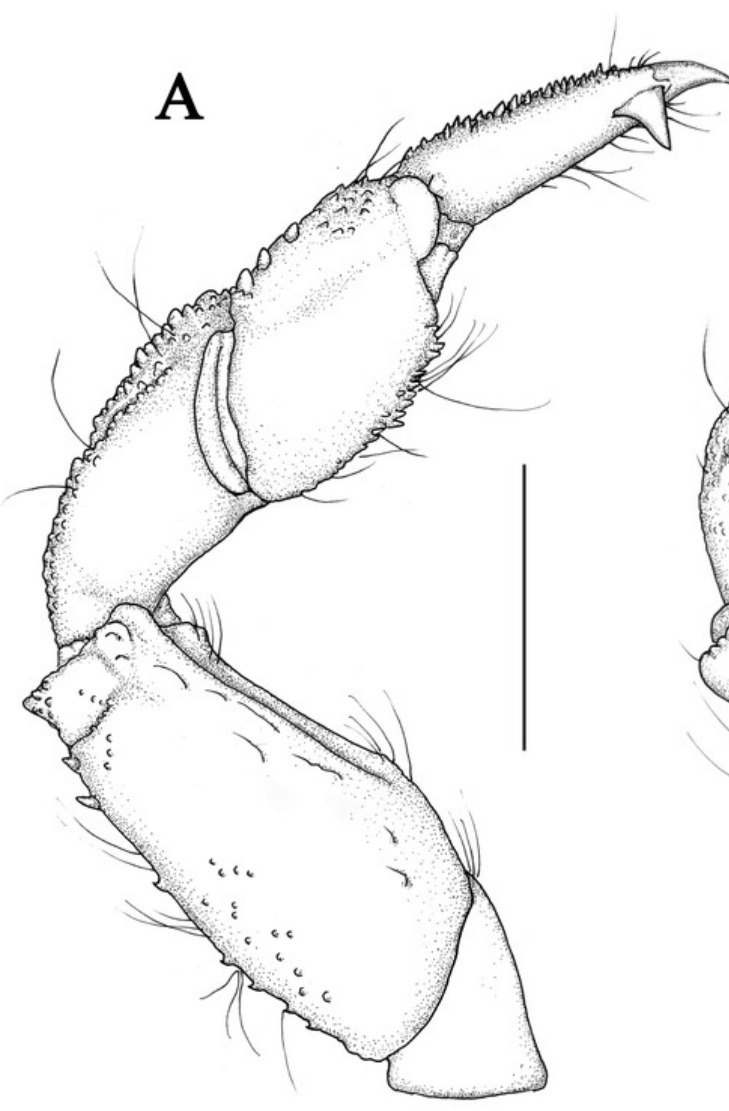

B
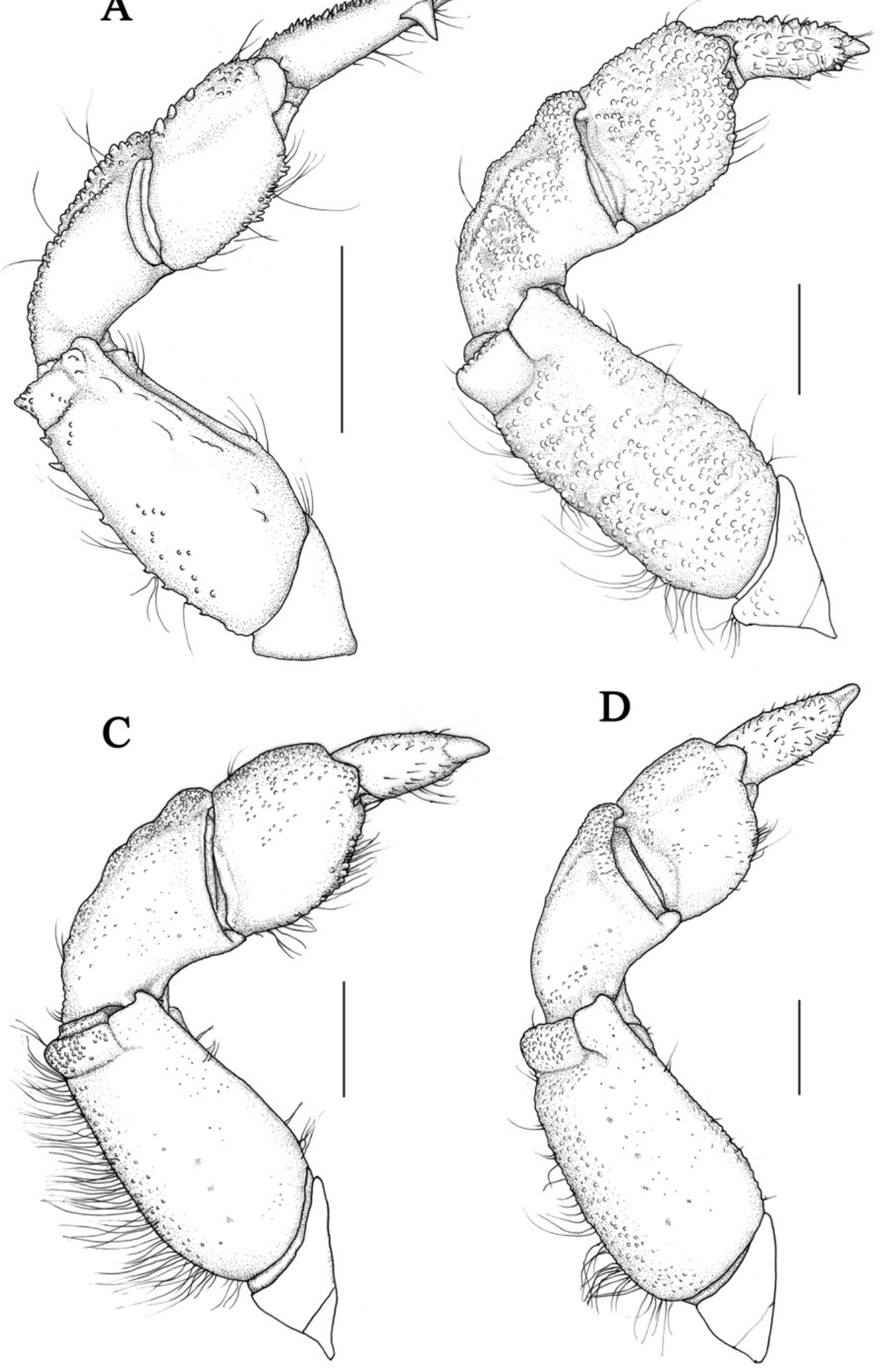


\section{Figure 7}

Left $\mathrm{Gl}$ of Macromedaeus species.

(A, E, I) M. orientalis (Takeda \& Miyake, 1969), male, 6.85×4.43mm (MBM286994). (B, F, J) M. distinguendus (De Haan, 1835), male, 27.76×18.21mm (135CC03764). (C, G, K) M. quinquedentatus (Krauss, 1843), male, $24.77 \times 15.60 \mathrm{~mm}$ (MBM286997). (D, H, L) M. crassimanus (A. Milne-Edwards, 1867), male, 29.69×18.46mm (MBM282426). (A-D) distal portion, internal view. (E-H) same, external view. (I-L) overall, internal view. Scale bars: (A, B, $E, F)=0.1 \mathrm{~mm} .(C, D, E, H)=0.2 \mathrm{~mm} .(I)=0.5 \mathrm{~mm} .(J-K)=1 \mathrm{~mm}$. 


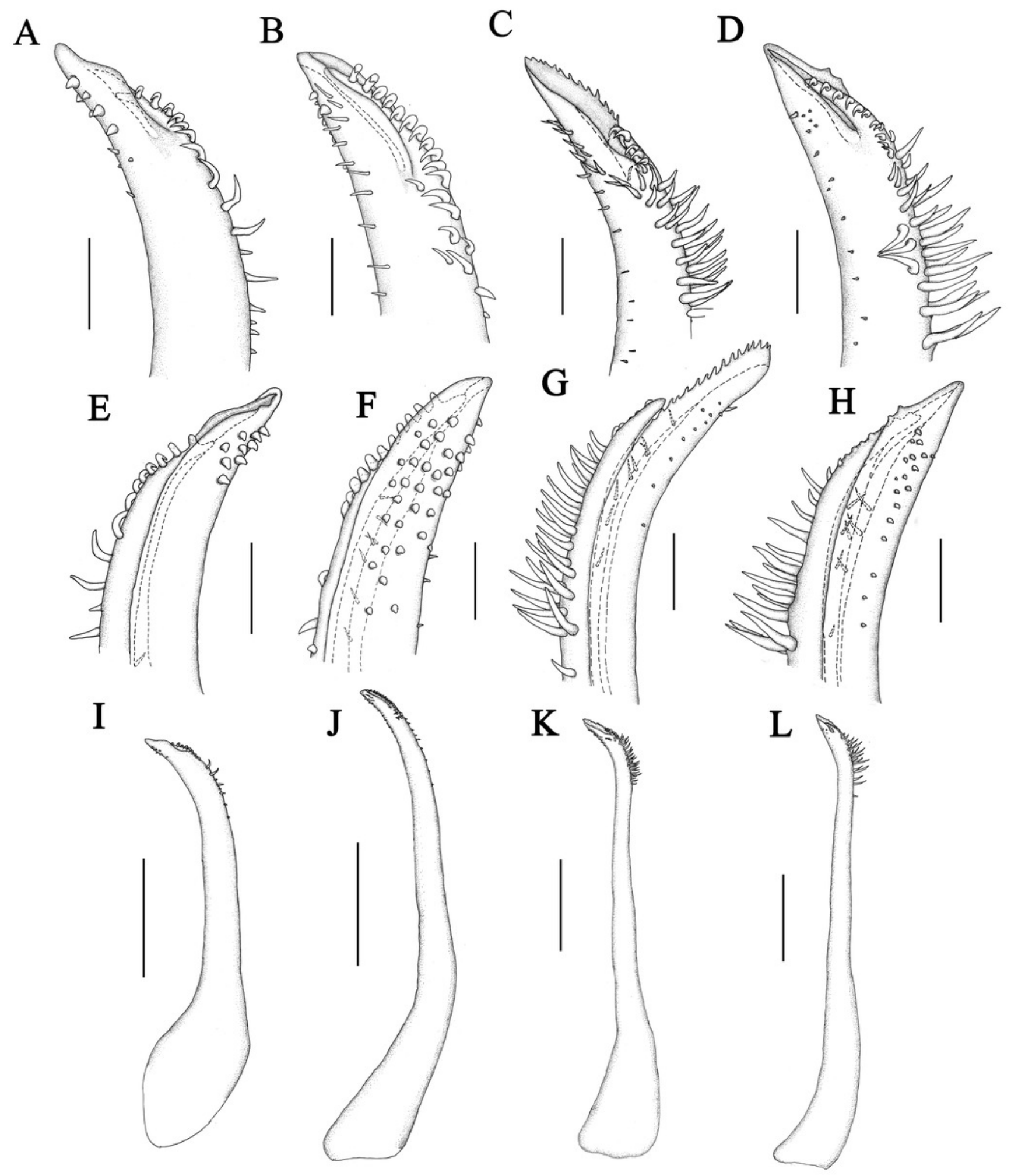


Figure 8

Macromedaeus distinguendus (De Haan, 1835), male, 27.76×18.21mm (135CC03764)

(A) overall, dorsal view. (B) carapace, dorsal view. (C) third maxillipeds and pterygostomian region, anterior view. (D) thoracic sternites and abdomen. (E) right cheliped, outer view. (F) left cheliped, outer view. Scale bars $=10 \mathrm{~mm}$. 


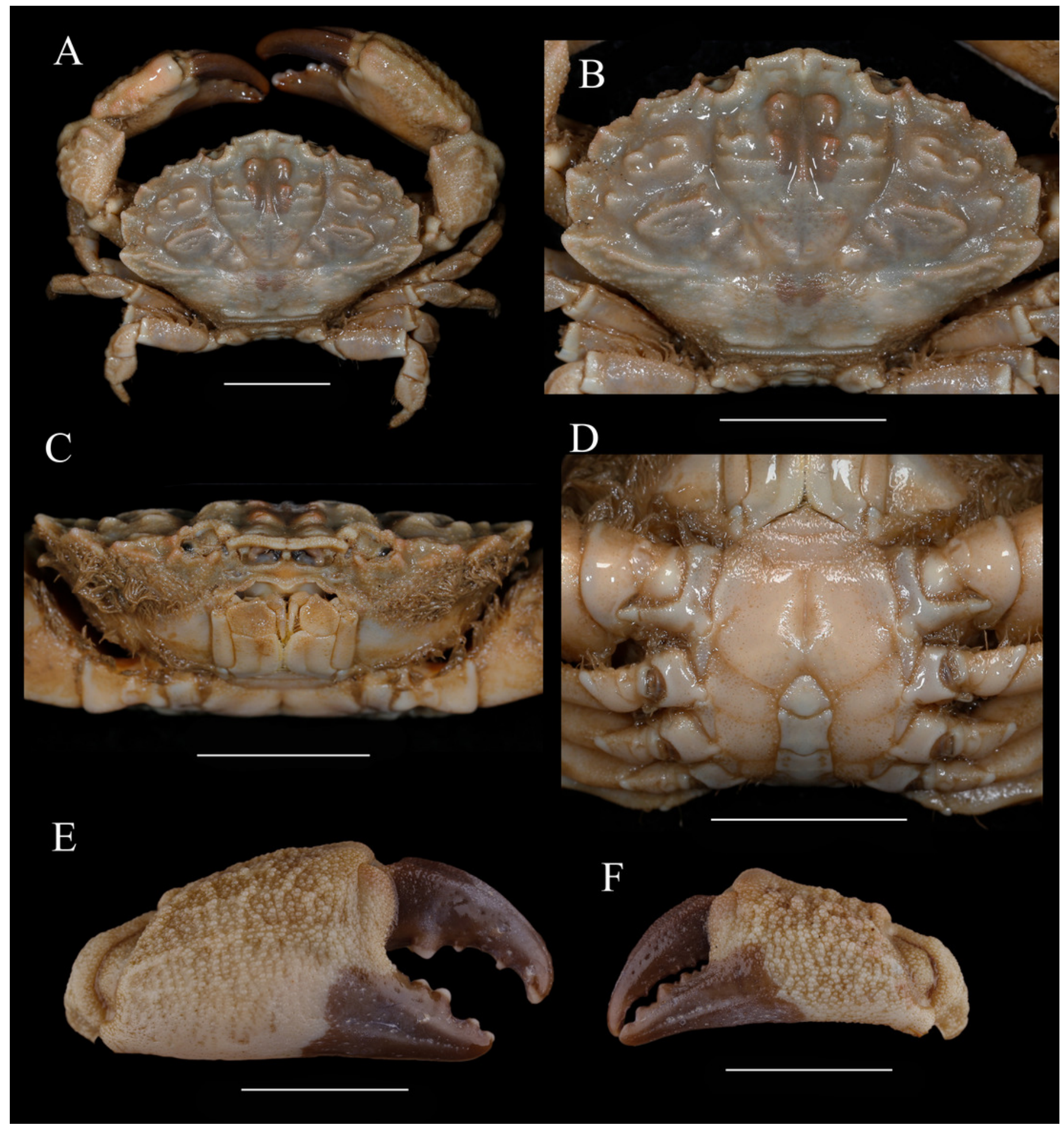


Figure 9

Macromedaeus distinguendus (De Haan, 1835)

(A, B, C) from Qingdao, Shandong. (D) from Xiamen, Fujian. (E, F) from Ningbo, Zhejiang.

Photo by Zhang Xu. 


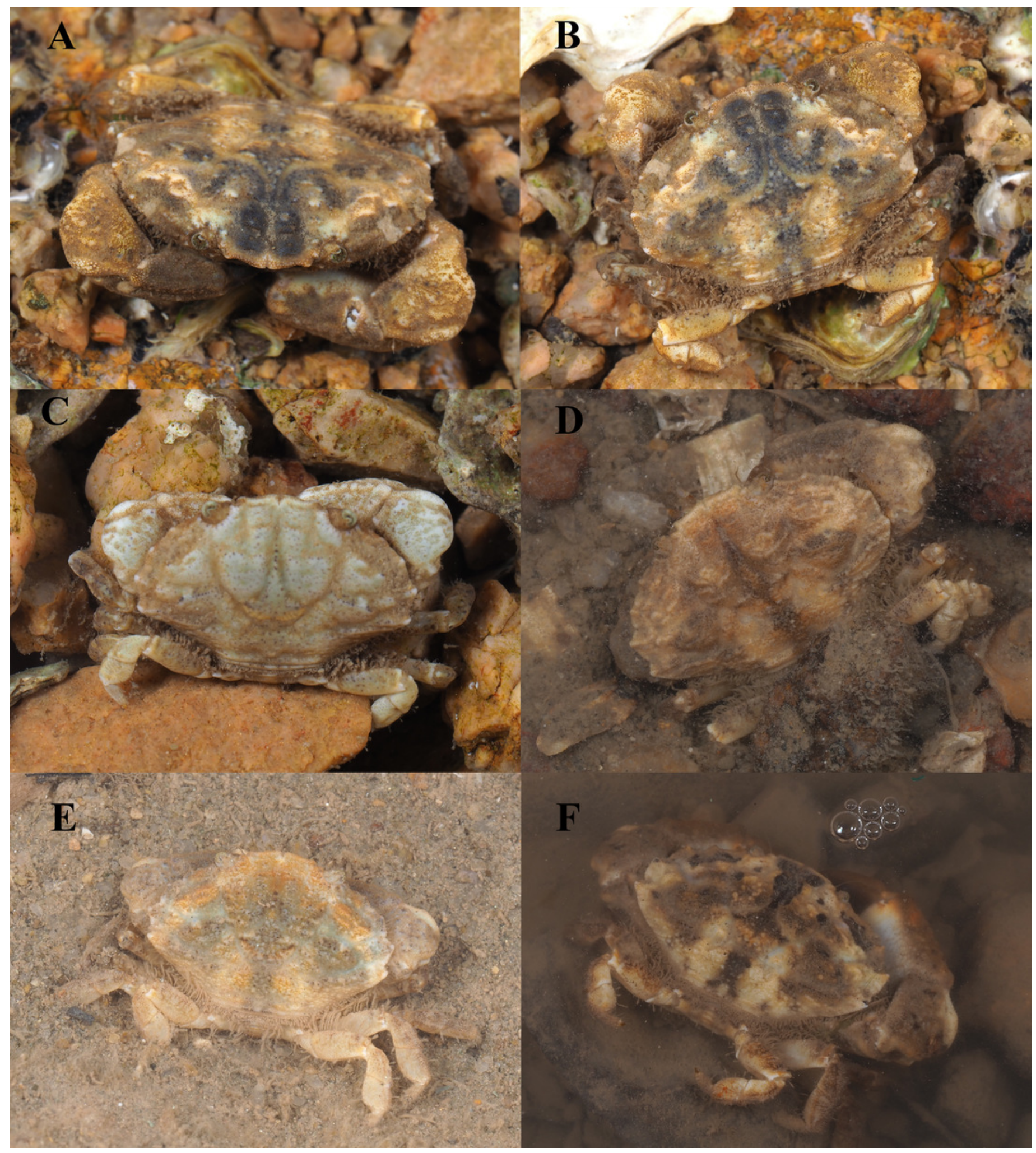




\section{Figure 10}

Macromedaeus distinguendus (De Haan, 1835)

(A) male, $28.9 \times 18.58 \mathrm{~mm}$ (MBM286999). (B) male, $27.76 \times 18.21 \mathrm{~mm}$ (135CC03764). (C) male, 23.19×15.75mm (MBM160925). (D) male, 24.14×16.04mm (MBM160943). Scale bars $=10 \mathrm{~mm}$.

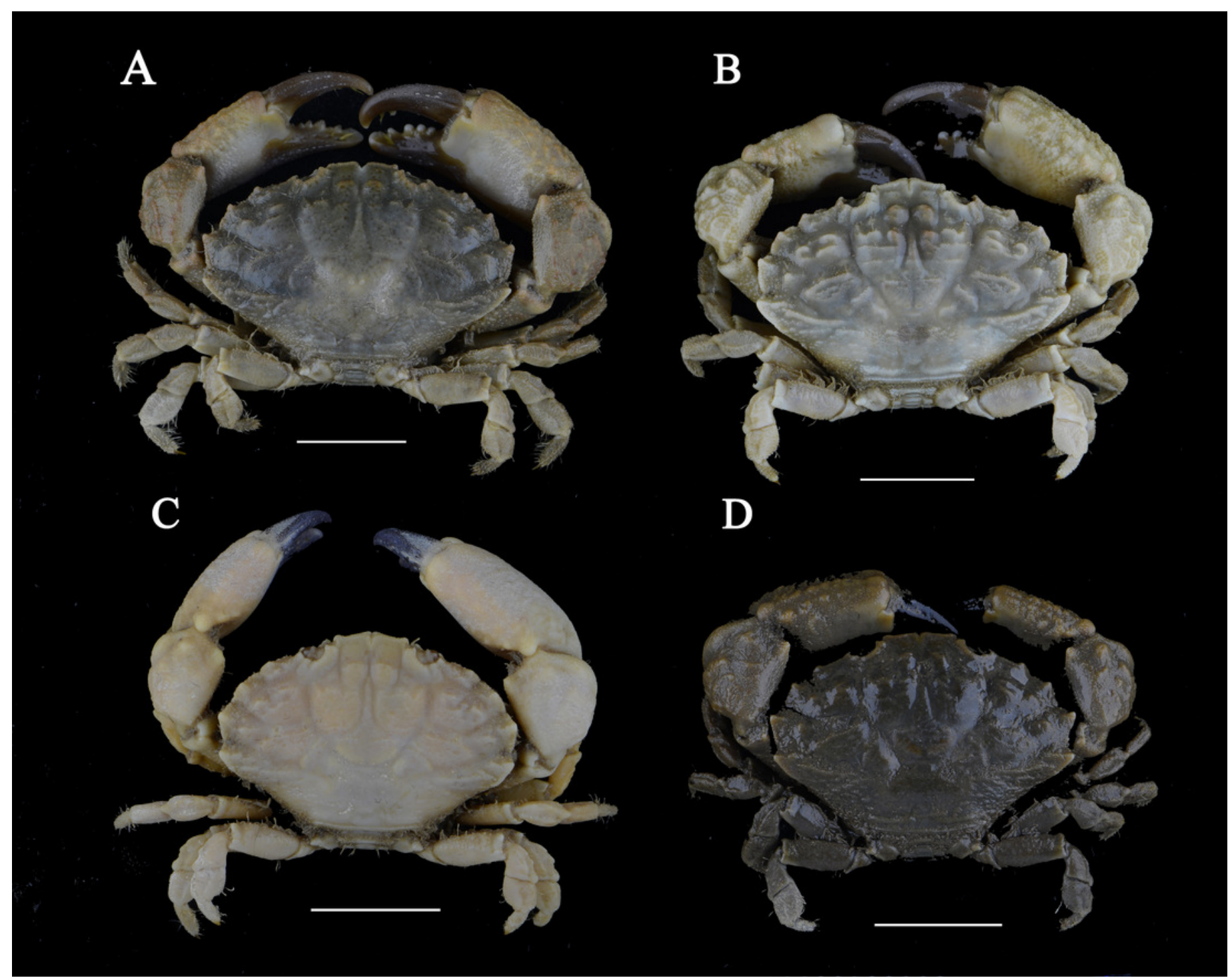




\section{Figure 11}

Macromedaeus quinquedentatus (Krauss, 1843), male, 24.77×15.60mm (MBM286997)

(A) overall, dorsal view. (B) carapace, dorsal view. (C) third maxillipeds and pterygostomian region, anterior view. (D) thoracic sternites and abdomen. (E) right cheliped, outer view. (F) left cheliped, outer view. Scale bars $=10 \mathrm{~mm}$. 


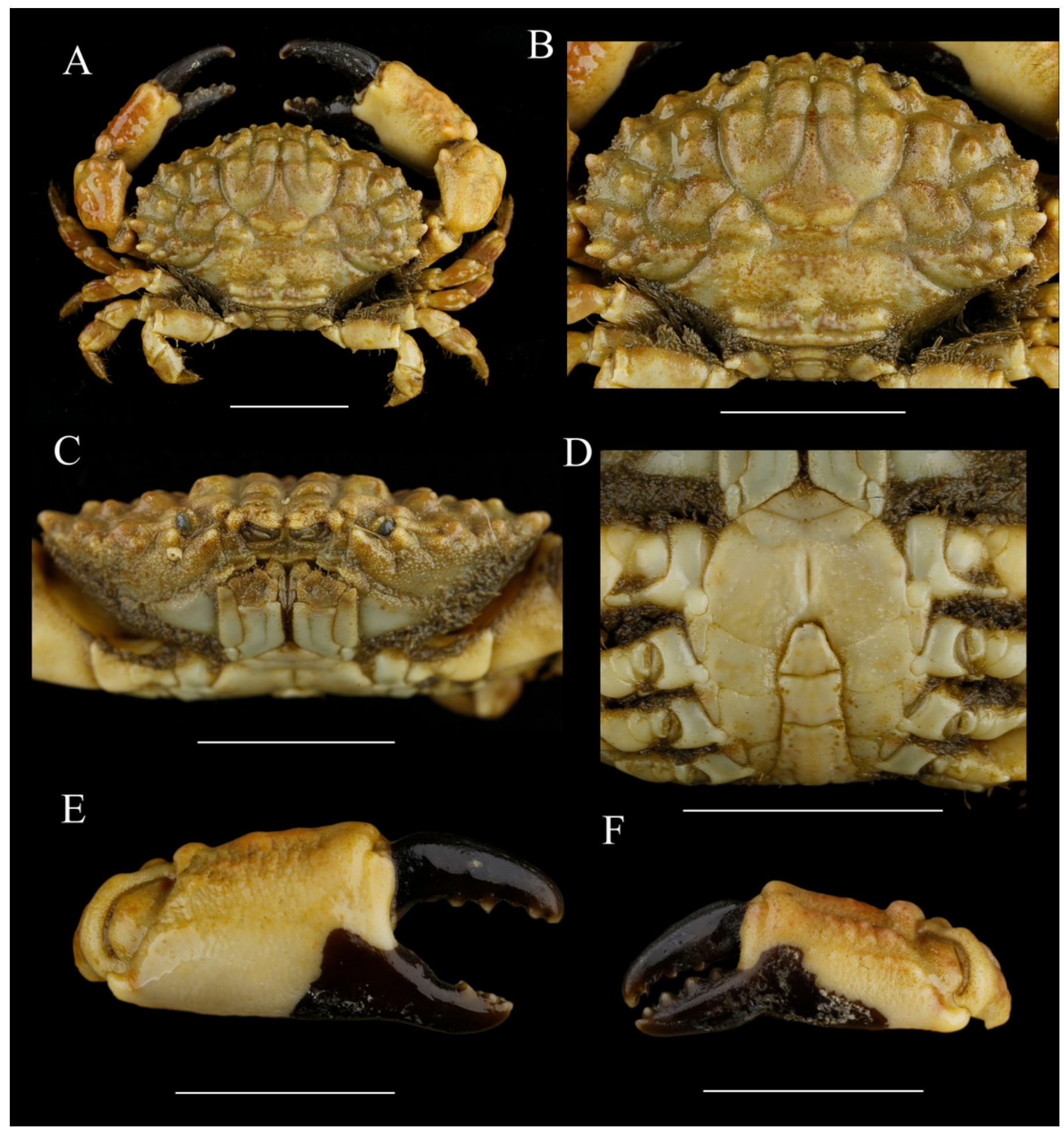




\section{Figure 12}

Macromedaeus crassimanus (A. Milne-Edwards, 1867), male, $29.69 \times 18.46 \mathrm{~mm}$ (MBM282426)

(A) overall, dorsal view. (B) carapace, dorsal view. (C) third maxillipeds and pterygostomian

region, anterior view. (D) thoracic sternites and abdomen. (E) right cheliped, outer view. (F) left cheliped, outer view. Scale bars $=10 \mathrm{~mm}$. 


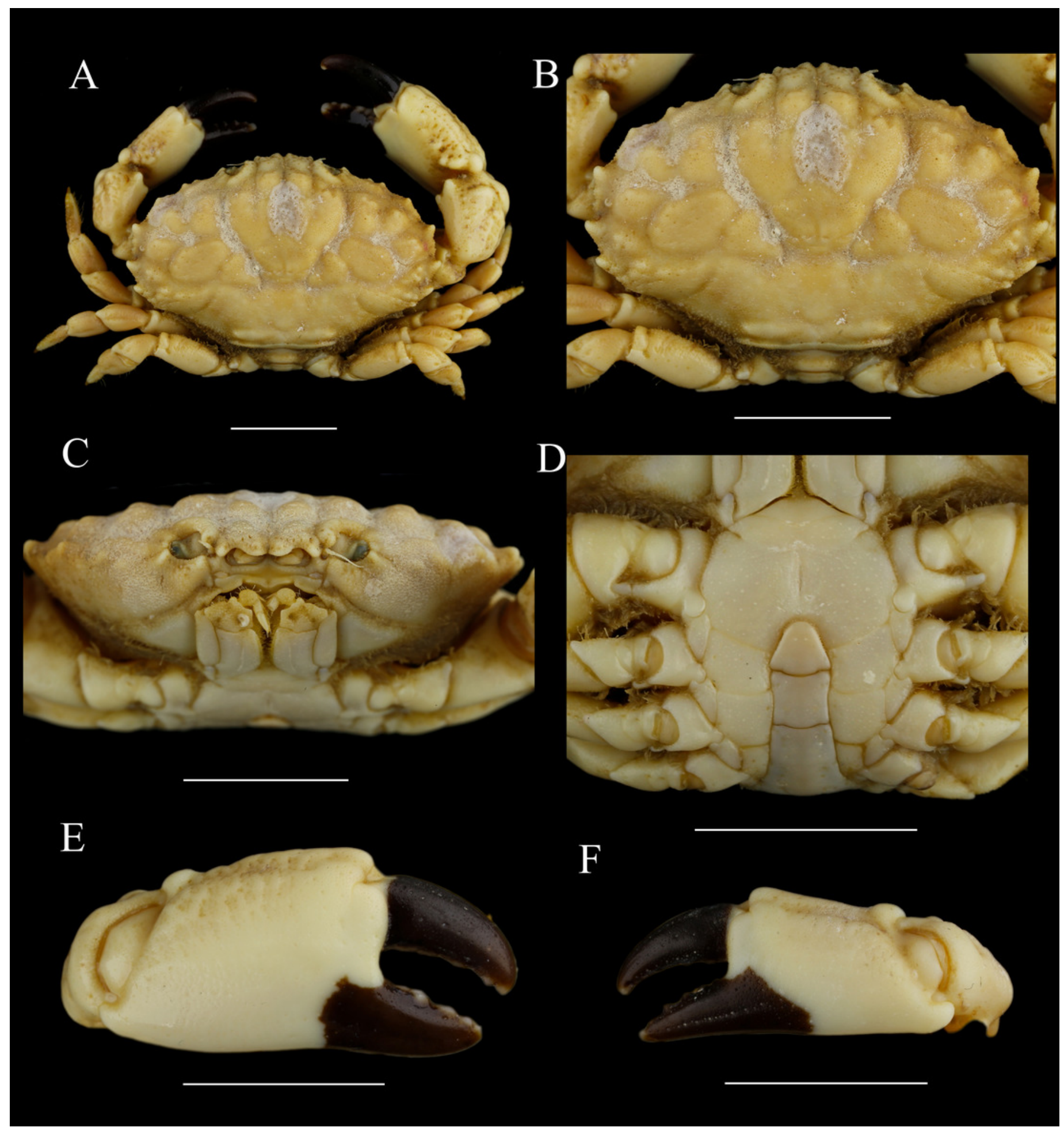




\section{Figure 13}

Phylogenetic relationships inferred from combined 12S, 16S, 18S, COI and H3

sequences among Macromedaeus species and related genus in Xanthidae, analyzed by Bayesian Inference (BI) and maximum likelihood (ML) analyses.

(A) BI tree, with posterior probabilities (PP) labeled. (B) ML tree, with bootstrap replications (BS) labeled, "-" represents values below 50. 


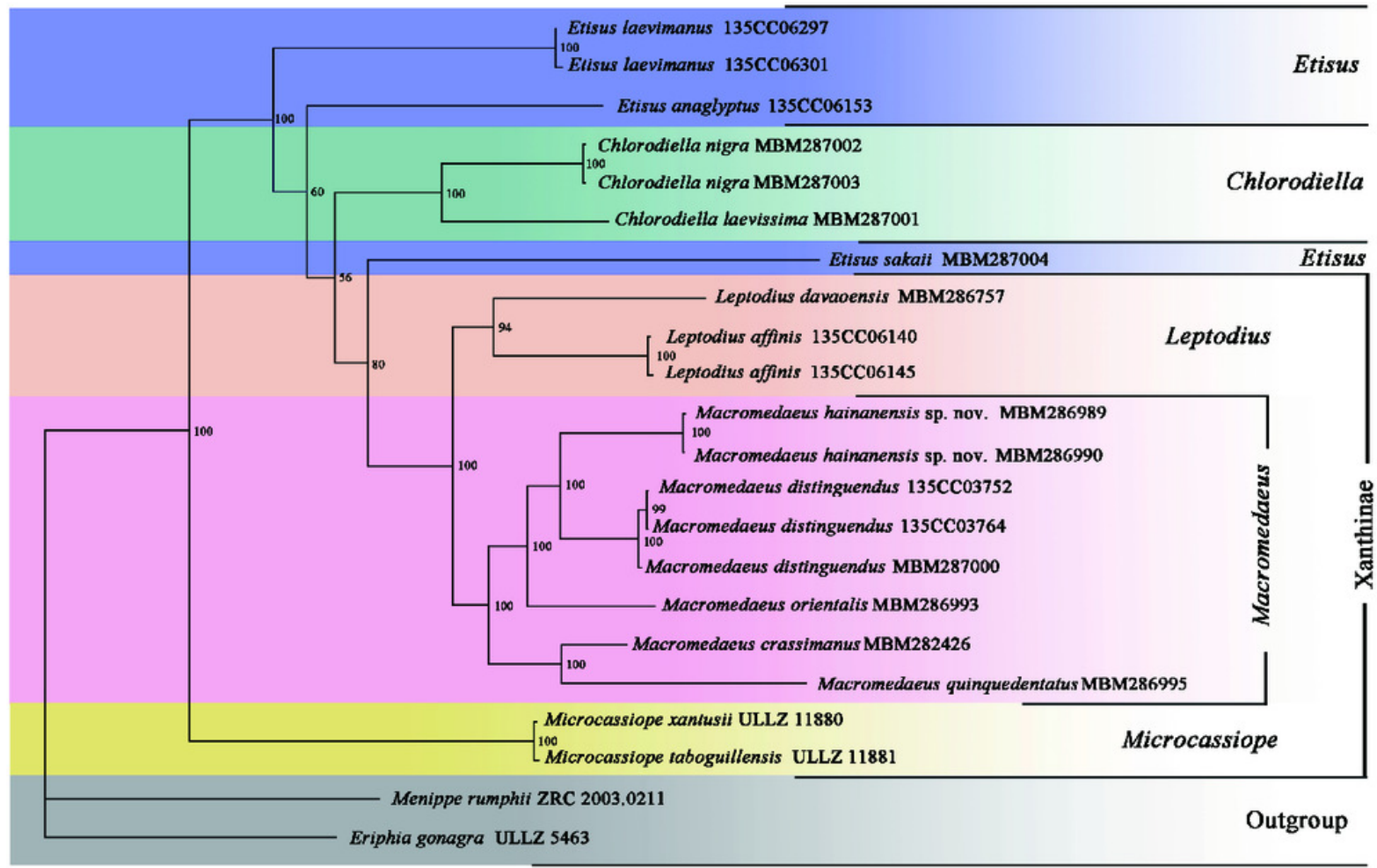

\section{B}

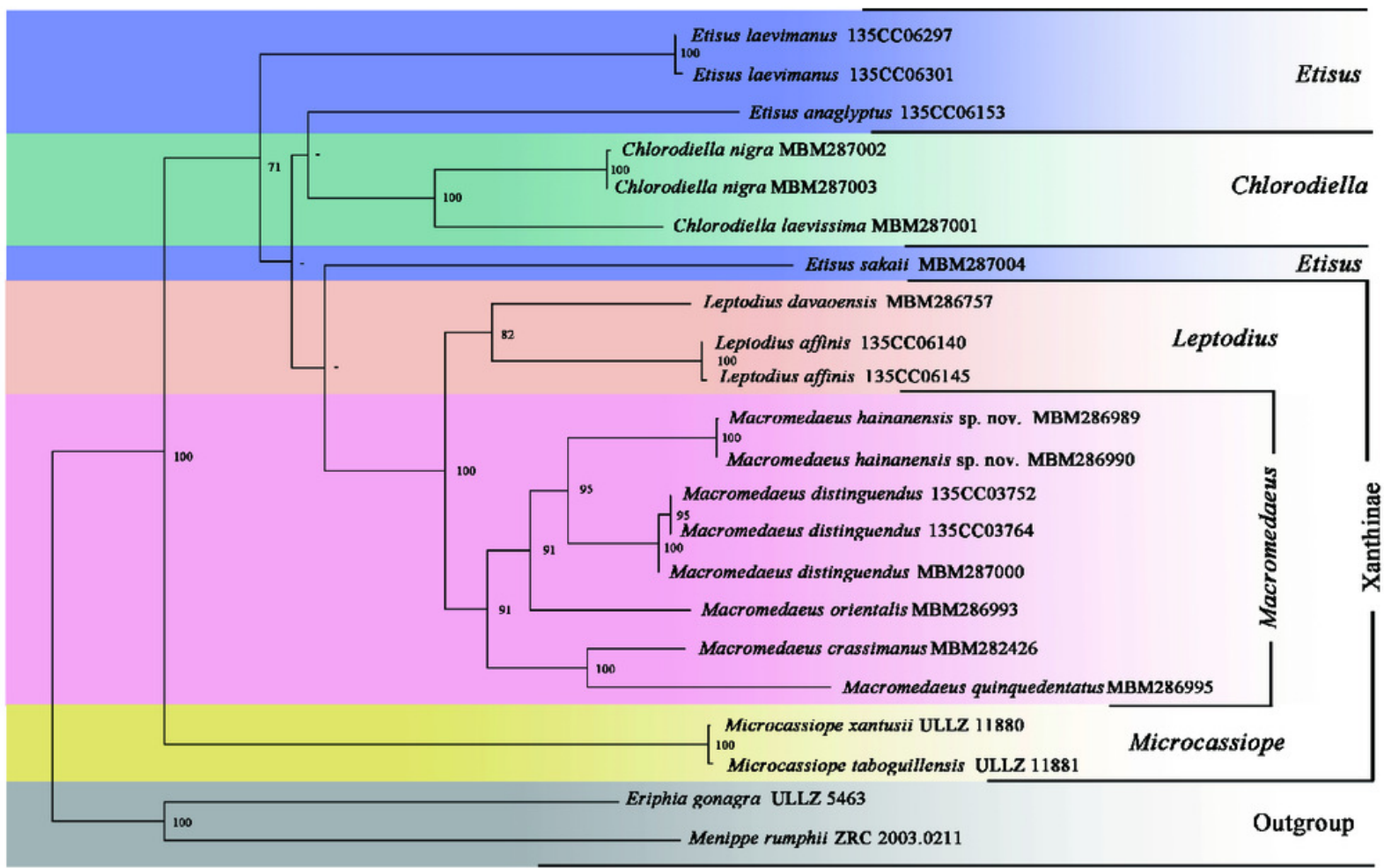




\section{Table 1 (on next page)}

Species and sequences used in the phylogenetic analysis with GenBank accession numbers and source. 


\begin{tabular}{|c|c|c|c|c|c|c|c|c|}
\hline \multirow[b]{2}{*}{ Species } & \multirow[b]{2}{*}{ Location } & \multirow[b]{2}{*}{ Voucher ID } & \multicolumn{5}{|c|}{ GenBank accession number } & \multirow[b]{2}{*}{ Sources } \\
\hline & & & $12 \mathrm{~S}$ & $16 \mathrm{~S}$ & $18 \mathrm{~S}$ & COI & $\mathrm{H} 3$ & \\
\hline $\begin{array}{l}\text { Macromedaeus crassimanus (A. } \\
\text { Milne-Edwards, 1867) }\end{array}$ & Xiaodonghai, Sanya, Hainan, China & MBM282426 & MZ901149 & MZ901133 & MZ901166 & $\mathrm{N} / \mathrm{A}$ & $\mathrm{N} / \mathrm{A}$ & Present study \\
\hline $\begin{array}{l}\text { M. crassimanus (A. Milne-Edwards, } \\
\text { 1867) }\end{array}$ & Balicasag Island, Philippines & ZRC 2003.0369 & N/A & $\mathrm{N} / \mathrm{A}$ & N/A & HM751018 & N/A & $\begin{array}{l}\text { Lai et al., } \\
2011\end{array}$ \\
\hline $\begin{array}{l}\text { M. crassimanus (A. Milne-Edwards, } \\
\text { 1867) }\end{array}$ & India & CASMBGM-1MC & N/A & $\mathrm{N} / \mathrm{A}$ & N/A & MG725244 & N/A & Unpublished \\
\hline M. distinguendus (de Haan, 1835) & Hepu, Guangxi, China & $135 \mathrm{CC} 03752$ & MZ901151 & MZ901135 & MZ901167 & N/A & MZ908676 & Present study \\
\hline M. distinguendus (de Haan, 1835) & Sanniangwan, Guangxi, China & $135 \mathrm{CC} 03764$ & MZ901152 & MZ901136 & MZ901168 & MZ900931 & MZ908677 & Present study \\
\hline M. distinguendus (de Haan, 1835) & Weihai, Shandong, China & MBM287000 & MZ901159 & MZ901141 & MZ901173 & MZ900938 & MZ908684 & Present study \\
\hline M. distinguendus (de Haan, 1835) & South Korea & DeB39 & N/A & $\mathrm{N} / \mathrm{A}$ & N/A & JX502906 & N/A & Unpublished \\
\hline M. distinguendus (de Haan, 1835) & South Korea & DeB41 & N/A & $\mathrm{N} / \mathrm{A}$ & N/A & JX502907 & N/A & Unpublished \\
\hline M. distinguendus (de Haan, 1835) & South Korea & DeB43 & N/A & N/A & N/A & JX502908 & N/A & Unpublished \\
\hline M. hainanensis sp. nov. & Mulan Bay, Wenchang, Hainan, China & MBM286989 & MZ901145 & MZ901129 & MZ901162 & MZ900926 & MZ908671 & Present study \\
\hline M. hainanensis sp. nov. & Mulan Bay, Wenchang, Hainan, China & MBM286990 & MZ901147 & MZ901131 & MZ901164 & MZ900928 & MZ908673 & Present study \\
\hline $\begin{array}{l}\text { M. orientalis (Takeda \& Miyake, } \\
\text { 1969) }\end{array}$ & Hainan, China & MBM286993 & MZ901146 & MZ901130 & MZ901163 & MZ900927 & MZ908672 & Present study \\
\hline M. quinquedentatus (Krauss, 1843) & Xiaodonghai, Sanya, Hainan, China & MBM286995 & MZ901150 & MZ901134 & N/A & MZ900930 & MZ908675 & Present study \\
\hline $\begin{array}{l}\text { Chlorodiella laevissima (Dana, } \\
\text { 1852) }\end{array}$ & Hainan, China & MBM287001 & MZ901148 & MZ901132 & MZ901165 & MZ900929 & MZ908674 & Present study \\
\hline C. nigra (Forskål, 1775) & Hainan, China & MBM287002 & MZ901142 & MZ901126 & MZ901160 & MZ900923 & MZ908668 & Present study \\
\hline C. nigra (Forskål, 1775) & Sanya, Hainan, China & MBM287003 & MZ901143 & MZ901127 & MZ901161 & MZ900924 & MZ908669 & Present study \\
\hline $\begin{array}{l}\text { Etisus anaglyptus } \mathrm{H} \text {. Milne } \\
\text { Edwards, } 1834\end{array}$ & $\begin{array}{l}\text { Weizhou Island, Beihai, Guangxi, } \\
\text { China }\end{array}$ & $135 \mathrm{CC} 06153$ & MZ901155 & MZ901138 & MZ901170 & MZ900934 & MZ908680 & Present study \\
\hline E. laevimanus Randall, 1840 & Lingchang reef, Lingao, Hainan, China & $135 \mathrm{CC} 06297$ & MZ901156 & MZ901139 & MZ901171 & MZ900935 & MZ908681 & Present study \\
\hline E. laevimanus Randall, 1840 & Lingchang reef, Lingao, Hainan, China & $135 \mathrm{CC} 06301$ & MZ901157 & MZ901140 & MZ901172 & MZ900936 & MZ908682 & Present study \\
\hline E. sakaii Takeda \& Miyake, 1968 & Sanya, Hainan, China & MBM287004 & MZ901158 & $\mathrm{N} / \mathrm{A}$ & N/A & MZ900937 & MZ908683 & Present study \\
\hline Leptodius affinis (De Haan, 1835) & Dachan reef, Danzhou, Hainan, China & $135 \mathrm{CC} 06140$ & MZ901153 & $\mathrm{N} / \mathrm{A}$ & MZ901169 & MZ900932 & MZ908678 & Present study \\
\hline L. affinis (De Haan, 1835) & Hainan, China & $135 \mathrm{CC} 06145$ & MZ901154 & MZ901137 & N/A & MZ900933 & MZ908679 & Present study \\
\hline L. davaoensis Ward, 1941 & Fengjiawan, Wenchang, Hainan, China & MBM286757 & MZ901144 & MZ901128 & N/A & MZ900925 & MZ908670 & Present study \\
\hline $\begin{array}{l}\text { Microcassiope taboguillensis } \\
\text { (Rathbun, 1907) }\end{array}$ & Cohiba Island, Panama & ULLZ 11881 & KF683035 & KF682967 & KF682854 & KF682825 & KF682573 & $\begin{array}{l}\text { Thoma et al., } \\
2014\end{array}$ \\
\hline $\begin{array}{l}\text { Microcassiope xantusii (Stimpson, } \\
\text { 1871) }\end{array}$ & Cohiba Island, Panama & ULLZ 11880 & KF683036 & KF683006 & KF682853 & KF682827 & KF682546 & $\begin{array}{l}\text { Thoma et al., } \\
2014\end{array}$ \\
\hline Eriphia gonagra (Fabricius, 1781) & Ft. Pierce, Florida, USA & ULLZ 5463 & HM637933 & HM637964 & HM637998 & HM638035 & HM596633 & $\begin{array}{l}\text { Lai et al., } \\
2011\end{array}$ \\
\hline Menippe rumphii (Fabricius, 1798) & Labrador Beach, Singapore & ZRC 2003.0211 & HM637946 & HM637976 & HM638015 & HM638051 & HM596626 & $\begin{array}{l}\text { Lai et al., } \\
2011\end{array}$ \\
\hline
\end{tabular}




\section{Table 2 (on next page)}

Genetic divergence of $\mathrm{COI}$ gene among the five species of Macromedaeus calculated from Kimura 2-Parameter-coreected calculations. 


\begin{tabular}{|c|c|c|c|c|c|}
\hline & M. crassimanus & M. distinguendus & M. orientalis & M. quinquedentatus & M. hainanensis sp. nov. \\
\hline M. crassimanus & 0 & & & & \\
\hline M. distinguendus & 0.133 & 0.000675106 & & & \\
\hline M. orientalis & 0.131 & 0.098 & N/A & & \\
\hline M. quinquedentatus & 0.124 & 0.133 & 0.135 & N/A & \\
\hline M. hainanensis sp. nov. & 0.130 & 0.097 & 0.109 & 0.136 & 0.001687764 \\
\hline
\end{tabular}

